\title{
Multi-scale relationship between land use/land cover types and water quality in different pollution source areas in Fuxian Lake Basin
}

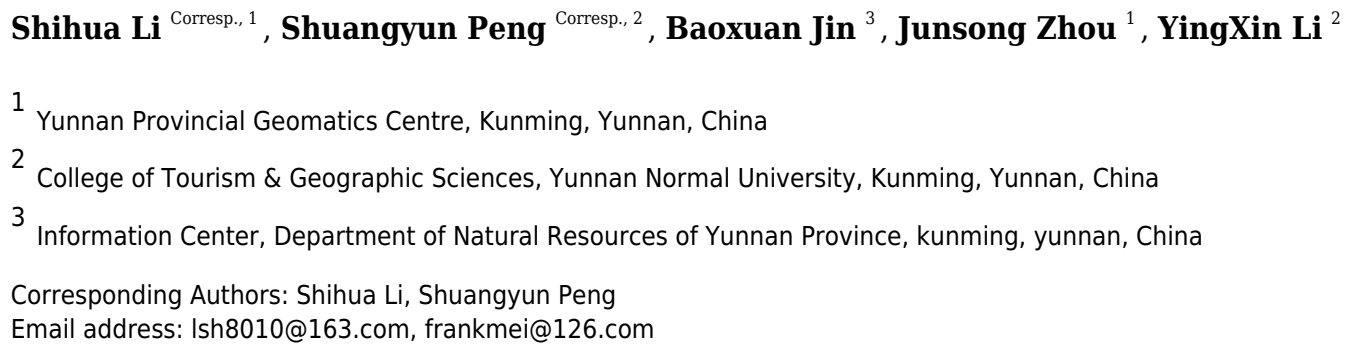

The spatial-temporal evolution of land use and land cover (LULC) and its multi-scale impact on the water environment is becoming highly significant in the LULC research field. The current research results show that the more significant scale impact on LULC and water quality in the whole basin and the riparian buffer scale is unclear. A consensus has not been reached about the optimal spatial scale problem in the relationship between the LULC and water quality. The typical lake basin of the Fuxian Lake watershed was used as the research area and the scale relationship between the LULC and water quality was taken as the research object. High resolution remote sensing images, archival resources of surveying, mapping and geographic information, and the monitoring data of water quality were utilized as the main data sources. Remote sensing and Geometric Information Technology were applied. A multi-scale object random forest algorithm (MSORF) was used to raise the classification accuracy of the high resolution remote sensing images from 2005 to 2017 in the basin and the multi-scale relationship between the two was discussed using the Pearson correlation analysis method. From 2005 to 2017, the water quality indicators (Chemical Oxygen Demand (COD), Total Phosphorous (TP), Total Nitrogen (TN)) of 9 rivers in the lake's basin and the Fuxian Lake center were used as response variables and the LULC type in the basin was interpreted as the explanation variable. The stepwise selection method was used to establish a relationship model for the water quality of the water entering the lake and the significance of the LULC type was established at $p<0.05$. The results show that in the 7 spatial scales, including the whole watershed, sub-basin, and the riparian buffer zone $(100 \mathrm{~m}, 300 \mathrm{~m}, 500 \mathrm{~m}, 700 \mathrm{~m}$, and $1000 \mathrm{~m}): 1$ ) whether it is in the whole basin or buffer zone of different pollution source areas, impervious surface area (ISA), or other land and is positively correlated with the water quality and promotes it. 2) Forestry and grass cover is another important factor and is negatively correlated with 
water quality. 3) Cropping land is not a major factor explaining the decline in water quality 4) The $300 \mathrm{~m}$ buffer zone of the river is the strongest spatial scale for the LULC type to affect the Chemical Oxygen Demand (COD). Reasonable planning for the proportion of land types in the riparian zone and control over the development of urban land in the river basin is necessary for the improvement of the urban river water quality. Some studies have found that the relationship between LULC and water quality in the $100 \mathrm{~m}$ buffer zone is more significant than the whole basin scale. While our study is consistent with the results of research conducted by relevant scholars in Aibi Lake in Xinjiang, and Erhai and Fuxian Lakes in Yunnan. Thus it may be inferred that for the plateau lake basin, the $300 \mathrm{~m}$ riparian buffer is the strongest spatial scale for the LULC type to affect COD. 
4 Shihua $\mathrm{Li}^{1}$, Shuangyun Peng ${ }^{2}$, Baoxuan $\mathrm{Jin}^{3}, \mathrm{Junnsong} \mathrm{Zhou}^{1}$, Yingxin $\mathrm{Li}^{2}$

$5 \quad{ }^{1}$ Yunnan Provincial Geomatics Centre, Kunming ,Yunnan, China

$6 \quad{ }^{2}$ College of Tourism \& Geographic Sciences, Yunnan Normal University, Kunming ,Yunnan,

7 China

$8{ }^{3}$ Information Center, Department of Natural Resources of Yunnan Province, Kunming, Yunnan,

9 China

10 Corresponding Author:

S.Y. Peng ${ }^{2}$

768 Juxian Street in Chenggong county, Kunming, Yunnan, 655000, China

Email address: frankmei@126.com

\section{Abstract}

The spatial-temporal evolution of land use and land cover (LULC) and its multi-scale impact on the water environment is becoming highly significant in the LULC research field. The current research results show that the more significant scale impact on LULC and water quality in the whole basin and the riparian buffer scale is unclear. A consensus has not been reached about the optimal spatial scale problem in the relationship between the LULC and water quality. The typical lake basin of the Fuxian Lake watershed was used as the research area and the scale relationship between the LULC and water quality was taken as the research object. High resolution remote sensing images, archival resources of surveying, mapping and geographic information, and the monitoring data of water quality were utilized as the main data sources. Remote sensing and Geometric Information Technology were applied. A multi-scale object random forest algorithm (MSORF) was used to raise the classification accuracy of the high resolution remote sensing images from 2005 to 2017 in the basin and the multi-scale relationship between the two was discussed using the Pearson correlation analysis method. From 2005 to 2017, the water quality indicators (Chemical Oxygen Demand (COD), Total Phosphorous (TP), Total Nitrogen (TN)) of 9 rivers in the lake' s basin and the Fuxian Lake center were used as response variables and the LULC type in the basin was interpreted as the explanation variable. The stepwise selection method was used to establish a relationship model for the water quality of the water entering the lake and the significance of the LULC type was established at $\mathrm{p}<0.05$. The results show that in the 7 spatial scales, including the whole watershed, subbasin, and the riparian buffer zone (100m, 300m, 500m, $700 \mathrm{~m}$, and 1000m): 1) whether it is in the whole basin or buffer zone of different pollution source areas, impervious surface area (ISA), or other land and is positively correlated with the water quality and promotes it. 2) Forestry and grass cover is another 
important factor and is negatively correlated with water quality. 3) Cropping land is not a major factor explaining the decline in water quality 4) The $300 \mathrm{~m}$ buffer zone of the river is the strongest spatial scale for the LULC type to affect the Chemical Oxygen Demand (COD). Reasonable planning for the proportion of land types in the riparian zone and control over the development of urban land in the river basin is necessary for the improvement of the urban river water quality. Some studies have found that the relationship between LULC and water quality in the $100 \mathrm{~m}$ buffer zone is more significant than the whole basin scale. While our study is consistent with the results of research conducted by relevant scholars in Aibi Lake in Xinjiang, and Erhai and Fuxian Lakes in Yunnan. Thus it may be inferred that for the plateau lake basin, the $300 \mathrm{~m}$ riparian buffer is the strongest spatial scale for the LULC type to affect COD.

\section{Introduction}

With the rapid development of the global society and economy, greater attention has been paid by the international academic community to research the effects that LULC has on the water environment by (Johnson,1997; Meneses, et al., 2015;Sajikumar,2015; Zhou, 2016) . The quality of the water environment of the basin is an important foundation for the harmonious development of hydrology-ecology-economics in the basin and unreasonable LULC changes are one of the vital characteristics that affect regional changes in the water environment (Zhang et al., 2003; Thomas et al., 2013). At present, the research on LULC type and water quality focuses on the response of water quality indicators such as TN (Total Nitrogen), TP (Total Phosphorous), pH (hydrogen ion concentration), CODMn (Chemical Oxygen Demand-Mn), TSS (Total - Soluble Solid), BOD5 (Biochemical Oxygen Demand, BOD), DO (Dissolved Oxygen), etc. to LULC changes from land use, land use structures, and land use patterns and has reached a consensus. There was a significant negative correlation between forest land, grassland, and water quality indicators, while arable land and construction land showed a strong positive correlation (Zhang et al., 2011; Yang et al., 2017). However, due to the multi-scale and distribution pattern of land use (Tu,2011;Zhou et al., 2012), there is a significant scale correlation between LULC changes and water quality indicators, which leads to uncertainty about the relationship between land use patterns and river water quality. From the saliency of spatial influence, the sub-basin scale is significantly higher than the riparian buffer scale (Sliva,2001; Jarvie et al., 2002; Woli et al.,2004;Li et al., 2012) , and some studies have reached the opposite conclusion (Sahu and Gu, 2009; Li et al., 2009;Huang et al., 2011;Ou et al., 2012) . The current research results show that the more significant scale impact on the land use and water quality in the whole basin and riparian buffer scale is unclear. The optimal or strongest spatial scale problem of the relationship between land use and water quality has not reached a unanimous conclusion (Johnson,1997;Sliva,2001;Shen,2015; Ding, 2016).

Fuxian Lake is a unique low-latitude and high-altitude plateau lake ecosystem. It is an important international lake in which to study the mechanism of biodiversity formation. Affected by the East Asian and Southwest monsoons, it is the most sensitive representative lake in response to global change and has become one of the hot spots of the research on international lakes, 
74 favored by experts and scholars at home and abroad.., It is one of the plateau lake basin systems

75 valued by researchers for having one of the most ecologically fragile areas in geoscience in

76 China. A literature review on Lake Fuxian reveals that many scholars have carried out research

77 on its hydrological and water qualities (Xia et al.,2007; Pan et al.,2008; Gao et al., 2013; Zhai et

78 al.,2015; Zhang et al.,2015; Yan et al.,2016; Yao et al.,2017; Chen et al.,2019), aquatic

79 organisms (Xiong et al., 2006; Li et al., 2007; Li et al.,2017), eutrophication (Li et al.,2003;

80 Zhang et al.,2012; Xu et al.,2016), LUCC (Liu et al.,2008; Li et al.,2015; Yang et al.,2016; Dai

81 et al.,2017; Li et al., 2017), soil erosion and land degradation (Yang et al., 2016;Ma et al., 2016),

82 vegetation change (Li et al., 2016), water environment economy (Xia et al., 2010; Gao et

83 al.,2014; Xiong et al., 2016), and sustainable development (Duan et al., 2013) based on remote

84 sensing, field monitoring, computer simulation, laboratory analysis, and other technologies.

85 Their results show that, in recent years, with an increase in global changes, a higher level of

86 urbanization, and the acceleration of social and economic development in the basin, the body of

87 Fuxian Lake has shrunken, the water level has decreased significantly, and the water area has

88 gradually narrowed. The LULC changes in the basin are significant, soil erosion and land

89 degradation are serious, and the ecological environmental quality of the basin is generally

90 declining (Yang et al., 2016; Ma et al., 2016; Li et al. 2017). The water quality of the river

91 entering the lake and the lake shore are severely polluted. Thus the water quality of the lake is

92 seriously threatened. Therefore, clarifying the scale relationship between the land use and water

93 quality will lay a foundation for the improvement and protection of the water quality in the basin.

94 Our goal in this paper was to investigate the historical shifts in LULC in Lake Fuxian between

952005 and 2017. We also examine the spatial scales at which these changes impact water quality

96 by monitoring the water quality data from the local department governing Lake Fuxian

97 throughout the watershed, together with data from five land cover maps (2005-2017). The present

98 study addresses the following research questions: (1) What land use category has the strongest

99 effect on water quality? (2) How do spatial and temporal variations in LULC within and across

100 watersheds influence water quality metrics in the Lake Fuxian watershed? (3) At what spatial

101 scale does the LULC type act to influence water quality? (4) How the multi-scale relationship

102 between land use types and water quality indicators can be used to balance relationship between

103 land use and water protection?

104 Materials \& Methods

105 General situation of the study region

106 Fuxian Lake is located in the center of the Central Yunnan Basin, Yuxi City, Central Yunnan

107 Province, China. It is China's largest deep-water freshwater lake, the first large lake as the

108 source of the Pearl River, and part of the Nanpan River system. Its geographical location is

$1092^{\circ} 21^{\prime} 28^{\prime \prime}-24^{\circ} 38^{\prime} 00^{\prime \prime} \mathrm{N}$ and 102 $49^{\prime} 12^{\prime \prime}-102^{\circ} 57^{\prime} 26^{\prime \prime} \mathrm{E}$ (Figure 1). As one of the nine plateau

110 lakes in the Yunnan Province, Fuxian Lake was the second deep-water lake explored in China

111 and the lake area and its water storage amount to the 8th and 3rd in China, respectively (Wang et

112 al., 1998). Because of the particularity of its geographical location, its powerful water supply

Peer] reviewing PDF | (2019:03:36121:1:2:NEW 30 May 2019) 
113 capacity, and its recreational value it is known as the "plateau pearl" in Central Yunnan. It

114 serves as an important and reliable resource for the sustainable social and economic development

115 in Central Yunnan, the strategic water resource for the regional development of the Pan-Pearl

116 River Delta, and an important strategic source of drinking water in the Pearl River Basin and

117 Southwest China (Gao et al., 2013). The water quality of Fuxian Lake is Class I and it is one of

118 the best natural lakes in China. The vegetation in the basin is mainly secondary vegetation such

119 as grass, shrub, and coniferous forest and the population reaches about 160,300. The rural

120 economy is dependent upon crop production, and the main food crops include rice, corn, and

121 wheat and economic crops include flue-cured tobacco and rape. Industry is dominated by the

122 phosphorus chemical industry, building materials, food processing, and aquatic products of

123 which the phosphorus chemical industry is the pillar industry of this area. The land use type of

124 the Fuxian Lake Basin has always been dominated by forests and water areas but with the

125 improvement of the urbanization level of the basin, human activities have increasingly disturbed

126 the natural environment, and phenomena such as the reclamation of lakes, deforestation, over-

127 exploitation of tourism resources, and the rapid increase of functional buildings have resulted in

128 a significant change in the land coverage types in the Fuxian Lake Basin.

\section{Data sources}

130 Because of the obvious seasonal variation of rainfall in the Fuxian Lake Basin and the large

131

132

133

134

135

136

137

138

139

140

141

142

143

144

145

146

147

148

149

150

151

152

seasonal variation of the lake area, the remote sensing images of relatively stable lake water levels during the dry season from January to March were selected. These include the 5 phases of high spatial resolution remote sensing image data in January 2008 (QuickBird satellite data, $0.61 \mathrm{~m}$ full color and $2.44 \mathrm{~m}$ multi-spectrum), January 2011 (WorldView-2 satellite data, $0.5 \mathrm{~m}$ full color and $1.8 \mathrm{~m}$ multi-spectrum), January 2014 (WorldView-2 satellite data, $0.5 \mathrm{~m}$ full color and 1.8m multi-spectrum), and March 2017 (Beijing No. 2 satellite data, $0.5 \mathrm{~m}$ full color and $1.8 \mathrm{~m}$ multi-spectrum) (Figure 2). Data was purchased from remote sensing image agents.

The reference data sources of orthorectified remote sensing images include 1:10000 DLG, $0.5 \mathrm{~m}$ resolution DOM of 1:25000, DEM data of $10 \mathrm{~m}$ grid spacing of the basin, 1:10000 out-of-flight control results, the three-space encryption results, 1:10000 DOM data results in the research area measured from 1985 to 2013, as well as achievements of the set basic GPS C-level points, triangle points of each level, military control points and standard points. The data are from the Yunnan Provincial Bureau of Surveying and Mapping. The training data and test data extracted by LULC adopts the WorldView-2 remote sensing image with a resolution of 0.5 meters in 2012 from the results of the first national geographical situation survey in the Yunnan Province and surface coverage classification data (water area, desert and bare surface, construction land, arable land, garden land, forest land, structure, grassland, road, and house building area), which were verified and modified in the field in 2014. The data are from the Yunnan Provincial Bureau of Surveying and Mapping. The auxiliary data for land use change driving force analysis and suitability atlas production includes the database of results from the first (1996) and the second (2006) national land survey of the study area, agricultural land grading results, and data from the land use planning database (updated in 2005 and other years), with data from Yuxi Municipal

Peer] reviewing PDF | (2019:03:36121:1:2:NEW 30 May 2019) 
153 Bureau of Land and Resources. The 13th Five-Year Plan of Fuxian Lake Basin (2016-2020), and 154 the data of Fuxian Lake Basin Planning are from the Fuxian Lake Administration Bureau of

155 Yuxi City. The annual average rainfall, annual average temperature, economy and population 156 data of the basin are obtained from the Statistical Yearbook of Yuxi City. The water quality 157 indicators were typically collected monthly TN, TP, and CODmn with the highest pollution load 158 in the main rivers and lakes in 2005, 2008, 2011, 2014, and 2017 and the three indicators were 159 obtained from monthly reports on the quality of the surface water provided by the Environmental 160 Monitoring Center of Chengjiang County.

161

162

163

164

165

166

167

168

169

170

171

172

173

174

175

176

177

178

179

180

181

182

183

184

185

186

187

188

189

\section{LULC information extraction}

The first-class classification system (water area, desert and bare surface, arable land, structure, garden land, grassland, forest land, house building, road and construction land) in the general survey contents and indicators of geographical conditions (GDPJ 01-2013) was adopted as a classification system for extracting LULC information of the remote sensing images. The definition of each type is shown in GDPJ 01-2013. Due to the differences between remote sensing image data sources and the time phase, training samples and test samples were collected from the remote sensing images in 2005, 2008, 2011, 2014, and 2017, respectively. For each LULC type of images in each phase, 2000 samples were collected, 70\% of which were used as training samples and $30 \%$ as test samples. The multi-scale object random forest (MSORF) algorithm (refer to Li (2008) for details) was used to obtain the LULC classification results of the river basin in 2005, 2008, 2011, 2014, and 2017. The classification accuracy Kappa is generally 0.8 or more, (i.e., 2005 (0.835), 2008 (0.812), 2011 (0.819), 2014 (0.822), and 2017 $(0.805))$. Referring to the current land use map and remote sensing images, the classified data are manually modified to form the final LULC information (Figure 3 ). To highlight the differences in the effects of the natural surface cover and human surface cover types on water quality, the LULC types were classified and combined according to the LULC type classification criteria. i.e., arable land and garden land merged into cropping land (CL), woodland and grassland merge into forestry and grass cover (FGL), buildings (districts), roads and structures were combined into an impervious surface area (ISA), the artificially excavated land, desert, and exposed surface were merged into other land (Other), and the water area was unchanged. The correlation analysis with the water quality of the rivers entering the lake was carried out at different spatiotemporal scales based on the combined LULC types.

\section{Scale definition}

Scale selection is related to the experimental design and the information collection in scale research, which is the starting point and foundation of our research. The selection of different scales will affect the comprehension of ecological patterns, processes, and their interactions to a certain extent and ultimately affect the scientific and practical research results (Lv et al., 2001). The discussion of the scale relationship between LULC and water quality is mainly focused on 
190 the basin and riparian buffer scales. It is generally believed that the $90 \mathrm{~m}, 100 \mathrm{~m}$, and $300 \mathrm{~m}$

191 riparian buffers are sensitive scales, while others consider that the whole basin scale is a sensitive 192 scale.

193 Three representative rivers that have been polluted by phosphate mines, urban development, and

194 village farmland were selected as the analysis objects after considering factors such as the 195 composition of the pollution source of the river basin, the topography and geomorphology, and 196 the LULC distribution. The Maliao River (MLH), which is seriously polluted by the county 197 town, the Daicun River (DCH) and the Dongda River (DDH) polluted by phosphate mines and 198 phosphorus chemical enterprises, and the Liangwang River (LWH), Shanchong River (SCH), 199 Jianshan River (JSH), Niu Mo River (NMH), Luju River (LJH) and Ge He River (GH) are 200 seriously polluted by the farmland in the nearby village. In order to facilitate comparison with 201 relevant research results, the response relationship between the water quality of the nine rivers 202 entering the lake in the above three types of regions and the corresponding sub-basin scale and 203 buffer-scale LULC type were analyzed. Based on the results of previous studies, the spatial scale 204 for exploring the relationship between the water quality and LULC is defined as: the riparian 205 buffer scale of the nine rivers $(100 \mathrm{~m}, 300 \mathrm{~m}, 500 \mathrm{~m}, 700 \mathrm{~m}, 1000 \mathrm{~m})$, sub-basin scales (MLH, $206 \mathrm{GH}, \mathrm{LJH}, \mathrm{SCH}, \mathrm{DDH}, \mathrm{DCH}, \mathrm{LWH}, \mathrm{JSH}, \mathrm{NMH}$ ) and the whole basin (Figure 4). The time scale 207 defines the interannual scale.

208 The processing of the riparian buffer was done under the ArcGIS platform. Based on the 209 topographical features of the basin, the sub-basin division was performed in the ArcSWAT tool 210 based on the DEM with $2 \mathrm{~m}$ grid spacing and water of the 1:10000 DLG in the study area.

211 Considering that the terrain of the north bank of the river basin is flat, in order to ensure that the 212 generated sub-basin was in line with the actual situation, a water network of 1:10000 DLG was 213 loaded into the Burn in a stream network to participate in the calculation. The 247 sub-basins 214 generated by automatic segmentation were recombined and were merged into 28 in total. The 9 215 main rivers entering the lake were extracted as sub-basins. The exit of the sub-basin was the 216 entrance into the lake and the scope of each sub-basin included the entire area upstream of the 217 outlet.

\section{Statistical analysis method}

219 The correlation between the water quality and LULC was analyzed based on the Pearson 220 correlation analysis method in the SPSS software. The monthly water quality indicators from 
2212005 to 2017 (Chemical Oxygen Demand (COD), Total Phosphorous (TP), Total Nitrogen (TN))

222 of the 9 rivers in the lake basin and the Fuxian Lake center were used as response variables, and

223 the LULC type in the basin was interpreted as an explanation variable. Using the stepwise entry-

224 removal (SER) method (Hu, 1990) to establishing a relationship model for the water quality of

225 the entering lake and the LULC type at $p<0.05$. The water quality index is the dependent

226 variable, and the LULC type is the independent variable in the model. The entry probability of

227 the model is 0.05 and the rejection probability is 0.1 .

228 Water quality evolution method

229 The three water quality indicators of the nine rivers were analyzed according to the "Surface

230 Water Environmental Quality Standard (GB3838-2002)" using the single index statistical

231 method in five time periods.

\section{Results}

\section{Water quality characteristics of the study area}

234 The water quality indicators COD, TN, and TP of the nine rivers entering the lake and the lake 235 center was analyzed using descriptive statistical methods. The results revealed that the COD 236 concentration in the rivers entering the lake ranged from 1.10 to $100.17 \mathrm{mg} / \mathrm{L}$, and the average 237 was $20.76 \mathrm{mg} / \mathrm{L}$. The TP concentration ranged from 0.025 to $2.54 \mathrm{mg} / \mathrm{L}$, and the average was $2380.32 \mathrm{mg} / \mathrm{L}$; the TN concentration ranged from 0.322 to $32.91 \mathrm{mg} / \mathrm{L}$, and the average was 7.75 $239 \mathrm{mg} / \mathrm{L}$. The three indicators of the lake's quality change very little, and TP and TN were basically 240 unchanged (Table 1).

241 According to the evolution of water quality it was found that among the 45 sections, the proportion 242 of COD in the class III to the inferior class V was $47.67 \%$, TP was $75.56 \%$; TN seriously exceeded 243 the standard, and the inferior $\mathrm{V}$ class accounted for about $90 \%$. The water quality of the lake center 244 was still in Class I.

\section{LULC variation characteristics}

246 The LULC information classification results can be used to further analyze the LULC variation 247 characteristics of the whole basin scale, village farmland areas, phosphate mine areas, and urban 248 watershed scales in different pollution source areas (Table 2).

249 It can be seen from Table 2 that under the whole basin scale, woodland and grass cover, 250 water, and cultivated land are the main LULC types in the basin （above 95\% of total area ), 
251 while other land accounts for approximately $2 \%$. The area of ISA and other land use has

252 generally increased and other land use has increased by nearly 5 times during the period starting

253 in 2005. The coverage of forest and grass and planting land has decreased but the area of water

254 has remained basically unchanged. The significant characteristic of LUCC can be summarized as

255 follows: the LULC type that is closely related to human economic activity shows strong growth

256 due to economic development and the increase in human activities.

257 Forest and grass cover, and crop land are the dominant LULC types in mountainous watersheds 258 from 2005 to 2017 . Their area accounts for about $65 \%$ and $27 \%$ of the mountainous watershed, 259 followed by impervious surfaces and waters, which accounts for $6 \%$ and $1 \%$ of the mountainous 260 watershed, and the smallest is other land, accounting for only about $0.3 \%$. Due to the economic 261 development of the basin and the increase of human activities, a large number of artificial digs, 262 deserts, and bare grounds have emerged resulting in an overall increase of the area of impervious 263 surfaces and other land uses. Since implementing the policy of returning farmland to forests in 264 2003, the area of planted land has decreased. While this is related to the planting structures and 265 patterns mainly based on economic crops (greenhouse vegetables, flowerbeds, nurseries, economic 266 forests, etc.). The coverage of forest and grass has decreased slightly due to the artificial 267 destruction of forest land in the mountainous areas natural succession, and land degradation, 268 however, the area of water has remained basically unchanged.

269 From 2005 to 2017 in the phosphate mine basin, forestry and grass cover and cropping land are 270 also the dominant LULC types. Their area accounts for $57 \%$ and $33 \%$ of the phosphate mine 271 watershed, respectively, followed by the impervious surface and other land use, which accounts 272 for about 5\% and 3\% of the phosphate mine basin, and the water area only accounts for about 273 1.4\%. The phosphate mine has been completely banned in the Fuxian Lake basin, however, the 274 mining area of the phosphate mine has left a variety of hidden dangers to the region, which has a 275 greater impact on soil and crops, resulting in a reduction in the area of planted land. The 276 implementation of a comprehensive ban on phosphate mining has resulted in a large number of 277 abandoned factories, phosphate deposits, artificially excavated land, and naturally degraded 278 deserts and exposed surfaces. However, the implementation of the ecological restoration project 279 in the phosphate mine area has shown an increasing trend in the impervious surface, other land 280 use, and forest -grass cover, and the area of water has remained basically unchanged. 
281 The forestry and grass cover, crop land, and impervious surface are the dominant LULC types in 282 the urban watersheds from 2005 to 2017 . Their area accounts for $48 \%, 30 \%$, and $20 \%$ of the urban 283 watershed, respectively, while other land and water areas account for only $1.9 \%$ and $1.1 \%$, 284 respectively. An increase in urbanization has led to the implementation of a large number of land 285 development projects in real estate, public facilities, and roads in the urban area which has 286 occupied a certain amount of planted land and forest and grass cover, creating a greater area of 287 hardened surface, building areas, structures and hardened road. These are accompanied by a great 288 number of construction projects or long-term shutdowns, resulting in a large number of artificial 289 digs or deserts and bare grounds. As a result, the area of planted land and the coverage of the forest 290 and grass are generally decreasing and the impervious surface and other land use are increasing, 291 while the area of water has remained basically unchanged.

\section{Multi-scale relationship analysis between LULC type and water quality}

293 Correlation analysis was carried out on the water quality of Fuxian Lake and the proportion of 294 LULC type area by the SPSS correlation analysis method. The results are shown in Table 3.

295 Note: ** indicates Sig. is a significant correlation at the 0.01 level (dual); * indicates Sig. is a 296 significant correlation at the 0.05 level (dual).

297 It can be seen from Table 3 that COD is closely related to other land, cropping land, and impervious 298 surface at the whole basin scale. Among them, COD is significantly positively correlated with 299 other land use and positively correlated with impervious surface but negatively correlated with 300 cropping land. TP was significantly positively correlated with cropping land and other land use 301 and positively correlated with impervious surface. However, there was a moderate negative 302 correlation with forestry and grass cover and water body, but the significance was low. TN has no 303 correlation with other LULC types except for a moderately positive correlation with impervious 304 surfaces.

305 In the urban basin, COD was closely related to cropping land, forest cover, and impervious 306 surfaces. Among them, cropping land was significantly negatively correlated with COD. TP was

307 moderately negatively correlated with forestry and grass cover, and water body, but the 308 significance was low; it was negatively correlated with cropping land, and had a low positive 309 correlation with impervious surfaces. With artificial land there was no correlation with artificial 310 digs, deserts, and bare ground. TN had no correlation with other land types except for a moderately 
negative correlation with forestry and grass cover.

312 In the phosphate mine basin, the phosphate mining area after reclamation was mostly in the LULC 313 states of artificial excavation, bare, and cropping land. Mining areas that have not been reclaimed 314 and mined are mainly classified as artificially excavated land and exposed ground. This feature is 315 better reflected in the analysis results in Table 3. The values of COD and TP were highly positively 316 correlated with other land types (ie, artificially excavated land, desert, and bare ground), and TP 317 was also highly positively correlated with cropping land and impervious surface.

318 In the village and farmland watershed, COD is moderately positively correlated with impervious 319 surfaces and other sites (ie, artificially excavated land, desert, and bare ground), and was 320 moderately negatively correlated with cropping land and forest, and grass cover, but the 321 significance was low. TP was significantly negatively correlated with cropping land and was 322 highly correlated with both forestry and grass cover, and impervious surface, but the forestry and 323 grass cover was inhibited by TP, while the impervious surface was the opposite. Other land and 324 TP were also positively correlated, but less significant. TN was significantly correlated with cropping land and forest cover with sig. values of 0.01 . The impervious surface was highly 326 positively correlated with TP, and the other land was moderately correlated with TP.

In summary, the effects of cropping land, forest cover, and impervious surface on TP and TN are grass cover can effectively improve and purify water quality. Increases in artificial excavation, desert, and bare surface led to the deterioration of water quality, but the sensitivity between the two is low.

Relationship model between LULC type and water quality in watershed scale

333 Based on the results of correlation analysis, using the significant variable $\mathrm{p}<0.05$ as the constraint, 334 the stepwise entry-removal method was used in the SPSS software to establish the water quality and LULC type multiple regression equations at the sub-basin scale (Table 4).

336 (Note: FarmL stands for cropping land, OthL stands for other land, and ISA stands for 337 impervious surface).

338 From the regression model in Table 4, it can be seen that the COD of the Maliao River Basin has 339 the strongest response to the cropping land, while the other water quality indicators and the LULC 
340 type response are not significant and the prepared significant $\mathrm{p}$ value standard was not achieved.

341 This is consistent with the results of the correlation analysis. In the phosphate mine basin, TP has

342 the best fit to regression models of other land types and impervious surfaces, which further 343 confirms that phosphate mining sites, bare ground surfaces, and impervious surfaces are one of the 344 important factors in the increase of TP in this region. Through regression models, it was found that 345 cropping land is one of the important indicators that led to higher TP and TN values in the village 346 farmland.

347 In the whole basin, COD has the strongest response to other land use, while TP has the strongest 348 correlation with cropping land. The TN index and LULC type response are not significant, and the 349 prepared significant p-value standard was not achieved, which is consistent with the correlation

350

351

352

353

354

355

356

357

358

359

360

361

362

363

364

365 366

367

368

369 analysis. It shows that the COD of the whole basin has the best fitting degree with the regression model of other land types, which further confirms that the basin phosphate mining point, bare surface, and artificial dig site are one of the important factors leading to the increase of COD value. Through the regression model, it was found that the proportion of planted land has a higher interpretation to TP, which mainly indicates that the area of planted land determines the application amount of chemical fertilizers and pesticides, and thus affects the TP concentration.

\section{Relationship between LULC type and water quality of rivers entering the lake at buffer scale}

The riparian zone serves as a transitional zone for the exchange of matter and energy between terrestrial and river ecosystems. The special geographical location determines its important functions and research value. The LULC type, structure, and function of the riparian zone will have a series of effects on the river water quality (Liu et al., 2016). Based on the nine main rivers in the different pollution source areas of the basin, the river buffer zones are generated at 100 meters, 300 meters, 500 meters, 700 meters, and 1000 meters. The relationship between the water quality and LULC types is explored and a relationship model based on the statistical analysis of the LULC structure of each buffer zone was built.

Correlation analysis was carried out on the water quality index of the rivers in the urban area, phosphate mine area, and village farmland, and the corresponding LULC types of the five riparian buffer zones. The results are shown in Table 5.

At the riparian buffer scale in the urban area, different LULC types have different effects on various water quality indicators, while the correlation between the LULC type and COD value is 
370 relatively close. Cropping land, forest cover, and water quality are negatively correlated. The 371 impervious surfaces and other land uses are positively correlated with water quality, and the 372 correlation between water and water quality is low. It shows that the impervious surface and other 373 land use on this scale are one of the important factors leading to the deterioration of water quality. 374 From the spatial scale, the significance of cropping land and COD is: $375500 \mathrm{~m}>300 \mathrm{~m}>700 \mathrm{~m}>1000 \mathrm{~m}>100 \mathrm{~m}$. Except for the $100 \mathrm{~m}$ scale, the significance level is 0.05 , and 376 the other scales are 0.01 . TP and TN also have a negative correlation with cropping land, but the 377 correlation coefficient is much smaller than COD. There is a negative correlation between the 378 forest and grass cover and water quality, indicating that forest and grass cover has a filtering effect 379 on pollutants and can reduce water pollution. Forest and grass cover have the greatest impact on 380 COD, followed by TN, and TP. Except for individual scales, the impervious surface is basically 381 positively correlated with water quality, and the relationship between COD and TP is most 382 significant on the scale of $500 \mathrm{~m}-1000 \mathrm{~m}$. Other land types are highly positively correlated with 383 COD and are highly sensitive at $300 \mathrm{~m}$. However, there is basically no correlation between other 384 land use and TP and TN, indicating that other sites have little or no effect on TP and TN.

385 At the riparian buffer scale in the phosphorus area, a more significant feature reveals that other 386 LULC types have a higher correlation with TP except for the lower correlation of waters. COD 387 and TN are weakly correlated or even not related to the other four types of land use except for the 388 correlation with artificial landfill, desert, and bare ground. The TP and LULC types in the phosphate mine zone show a high correlation and sensitivity. This fully demonstrates that densely distributed phosphate deposit sites and phosphorus chemical companies are the main sources of phosphorus pollution in the region.

392 Compared with the urban scale and the phosphate mine scale, the sensitivity between water quality 393 indicators and the LULC type is significant in village farmland. The LULC type has a significant 394 correlation with TN. There was a negative correlation between cropping land and COD, TP, and TN among which TN was the most significant, TP was the second, and COD was the lowest. The degree of correlation with $\mathrm{TN}$ is somewhat different at each buffer scale. The order of significance is: $700 \mathrm{~m}>1000 \mathrm{~m}>500 \mathrm{~m}>300 \mathrm{~m}>100 \mathrm{~m}$, which is basically consistent with TP. The degree of correlation with COD is low, with a moderate negative correlation between $500 \mathrm{~m}$ and $1000 \mathrm{~m}$, and a low negative correlation between $100 \mathrm{~m}$ and $300 \mathrm{~m}$. 
400 There was a moderate negative correlation between forest and grass cover and TN and TP. It was 401 negatively correlated with COD at 500m-1000m, and the correlation between $100 \mathrm{~m}$ and $300 \mathrm{~m}$ was 402 not obvious.

403 The degree of impervious surface and water quality correlation was: $\mathrm{TN}>\mathrm{TP}>\mathrm{COD}$. This law is 404 exactly the opposite of that for other land use and water quality. The correlation between other 405 land (artificial dig, desert and bare ground) and water quality is COD $>$ TP $>$ TN. This phenomenon 406 indicates the impervious surface and other land use play different roles in the increase of water 407 quality indicators in the region. The impervious surface mainly leads to the increase of the TN 408 index, and other land use leads to the increase of the COD index. From the buffer scale in the 700m 409 buffer zone, the correlation between the impervious surface and water quality is still the highest, 410 followed by $300 \mathrm{~m}$, while the correlation between other land and water quality has a certain degree 411 of differentiation, and TN and TP basically have $1000 \mathrm{~m}-100 \mathrm{~m}$ in a gradually decreasing trend, 412 which is exactly the opposite of COD. The proportion of the water area is basically within $4 \%$, and 413 the correlation with water quality is small.

\section{Relationship model between river water quality and LULC under buffer scale}

415 The multivariate regression equation of water quality and the LULC type at the riparian buffer 416 scale is constructed by the SER method in the different pollution source areas (Table 6).

417 Table 6 shows that the LULC types in different regions reveal significant differences on water 418 quality indicators. The urban area has a greater impact on COD and the phosphate mine area has 419 a greater impact on TP. The village farmland area has a greater impact on TN. The impact of the 420 urban LULC type on COD is: $300 \mathrm{~m}>500 \mathrm{~m}>$ sub-basin $>700 \mathrm{~m}>1000 \mathrm{~m}>100 \mathrm{~m}>$ whole basin; the 421 effect of the LULC type on COD in the phosphate mine area is: $300 \mathrm{~m}>500 \mathrm{~m}>$ whole 422 basin $>100 \mathrm{~m}>$ sub-basin $>1000 \mathrm{~m}>700 \mathrm{~m}$; the influence of the LULC type on TP in the phosphate 423 mine area is: $700 \mathrm{~m}>500 \mathrm{~m}>$ sub-basin $>300 \mathrm{~m}>$ whole basin $>1000 \mathrm{~m}>100 \mathrm{~m}$, the influence of the 424 LULC type on TN in village farmland is: $700 \mathrm{~m}>1000 \mathrm{~m}>$ sub-basin $>500 \mathrm{~m}>300 \mathrm{~m}>100 \mathrm{~m}$. The 425 impact of the LULC type on $\mathrm{TP}$ in village farmland is: sub-basin $>$ full basin $426700 \mathrm{~m}>1000 \mathrm{~m}>500 \mathrm{~m}>300 \mathrm{~m}>100 \mathrm{~m}$. From the sorting point of view, the urban areas and phosphate 427 mines have a greater impact on COD and TP at $300 \mathrm{~m}, 500 \mathrm{~m}$, and $700 \mathrm{~m}$, while in the village 428 farmland, the sub-basin scale has a greater impact on water quality.

429 Discussion, The percentage of area of ISA and other land (man-made land, desert, and 
430 bare ground) is positively correlated with water quality, regardless of whether it is in the whole 431 basin or buffer zone of different pollution source areas, which has a positive effect and is consistent 432 with relevant research conclusions (Osborne,1998; Basnyat et al., 1999;Sliva et al., 2001;Guang 433 et al., 2008; Huang et al., 2011; Yang et al., 2017;Xiang et al., 2018). ISA and other land use ratios 434 are positively correlated with COD and TP. This is mainly due to the fact that the amount of 435 organic matter and phosphorus loss is closely related to the content and concentration of runoff. 436 The acceleration of urbanization has led to an increase in the area of artificial buildings and the 437 surface area of impervious surfaces has increased accordingly. Pollutants such as roads, plazas, 438 and roofs are more likely to converge and carry large amounts of sediment, nutrients, and heavy 439 metal contaminants, which easily flow into the river, creating a burden on the river.. In addition, 440 the discharge of industrial and domestic wastewater from urban areas into water bodies can also 441 cause the water quality to decline (Fedorko et al., 2005).

442 Forest and grass covers are another important factor affecting water quality and are negatively 443 correlated with water quality. This is consistent with the expected understanding that forest and 444 grass cover can improve water quality. Forest and grass cover can reduce runoff, thereby reducing 445 soil erosion and water quality degradation due to soil erosion. The results show that most of the 446 water quality parameters that characterize the water quality decline are negatively correlated with 447 the percentage of forest cover area, which is consistent with other research conclusions. The 448 vegetation as a "sink" of pollutants confirms that vegetation has the effect of intercepting and 449 purifying pollutants (Osborne et al., 1993; Sliva et al., 2001; Novotny et al., 2002; Bahar et al., 450 2008; Lopez et al., 2008; Zeng et al., 2012; Putro et al., 2016).

451 Cropping land is not a major factor in explaining the decline in water quality. At the whole basin 452 scale, TP has the strongest correlation with cropping land, and the TN index is not significant. The 453 impact of cropping land on water quality is complex and negatively correlated with TN and TP.

454 455 456 457 458 459 460 This is consistent with the conclusion that the proportion of agricultural land is negatively correlated with TN (Lenat et al., 1994; Johnson et al., 2010; Sliva, 2001; Chang, 2008;Tu,2008). However, it is also different from some studies (Fedorko et al., 2005; Bahar et al., 2008). This indicates that the area ratio of agricultural land is not the main factor affecting TN, which is related to the application amount of pesticides and fertilizers, planting structure, and the distance from the receiving water body and topography. At the same time, the cropping land contributes a large amount of nutrient salt to the river through fertilization with farmland runoff, yet it also acts as a 
461 vegetation or wetland system to attach, absorb, and retain pollutants. From the spatial distribution 462 of LULC in the Fuxian Lake basin, the arable land in the Fuxian Lake Basin is mainly distributed 463 throughout the mountainous areas and the flat area on the north bank of Fuxian Lake. The river 464 that enters the lake passes through this arable area and then flows into Fuxian Lake. The arable 465 land in the flat area has a certain retention and retention effect on the $\mathrm{TN}$ of the river into the lake 466 and is related to the natural characteristics of TN and its migration and transformation (Pang et al., 467 2015). A large number of microorganisms in the arable land are beneficial to nitrification and 468 denitrification between the different forms of nitrogen (Zeng et al., 2012; Li et al., 2016). However, this is related to the policies and implementation of the prevention and control of non-point source 470 pollution in the Fuxian Lake Basin by the Yunnan Provincial Government and the Yuxi Municipal

471 Government in recent years. These policies and measures limit the use of ammonia and phosphate 472 fertilizers and pesticides in the basin, resulting in a negative correlation between TN, TP, and 473 planted land.

474 From the perspective of the spatial effects of the LULC types and water quality, there are 475 significant spatial scale differences in the relationship between the LULC types and water quality, 476 and the spatial scale differences in various regions are unique. Most studies have shown that LULC 477 has the highest interpretation rate of water quality at the small watershed scale and it is the spatial 478 scale with the strongest impact on the water quality of the river (Slivaet al., 2001; Tudesque et al., 479 2014; Ding et al., 2016). However, some studies have found that the relationship between LULC 480 and water quality in the $100 \mathrm{~m}$ buffer zone is more significant than the whole basin scale (Shen et 481 al., 2012; Zhou et al., 2015). Those results are different from the results of this study and are 482 related to the LULC characteristics of the study area itself. At the sub-basin scale, forest and grass 483 cover is the dominant land type, accounting for more than $50 \%$ of the area, much higher than other 484 land types. The superior land use type is prominent, which consistently creates a higher 485 interpretation rate of its relationship with water quality. Compared with the riparian buffer scale, 486 cropping land, ISA, forest and grass cover together constitute a dominant land type, and the land 487 type components are complex and the effects of various types on water quality are different.

488 The existence of superposition or "waxing and waning" results in a lower interpretation rate of 489 water quality than the sub-basin scale (Chang 2008; Tudesque et al., 2014; Yu et al., 2015;Xiang 490 et al., 2018). The results show that the $300 \mathrm{~m}$ riparian buffer zone in the urban watershed is the 491 strongest spatial scale for the LULC type to affect COD. This is consistent with the results of 
492 research conducted by relevant scholars in Aibi Lake in Xinjiang, Erhai and Fuxian Lake in

493 Yunnan (Liu et al., 2008; Cao et al., 2018; Xiang et al., 2018). It can be inferred that for the plateau

494 lake basin, the $300 \mathrm{~m}$ riparian buffer is the strongest spatial scale for the LULC type to affect COD.

495 This inference needs further verification. However, due to the different contributions of ISA and

496 cropping land to the generation and emission of pollutants, the influence of different spatial

497 patterns on the pollution of river waters presents a "waxing and waning" relationship. Therefore,

498 it is necessary to properly plan the proportion of land types in the riparian zone and control the 499 development of urban land in the river basin.

\section{Conclusions}

501 The quality of water entering the lake is generally poor, while the quality of water in the

502 lake center is still type I. The annual average water quality of the rivers entering the lake is

503 inferior to the V category. Chemical Oxygen Demand (COD) in 45 sections had the highest

504 proportion of type I and type II, reaching 53.33\%, the other types of Total Phosphorus (TP) were

505 evenly distributed, accounting for 22-26\%. Total Nitrogen (TN) seriously exceeded the standard,

506 revealing that nearly $90 \%$ of the water quality is inferior $\mathrm{V}$. The spatial variation of the water

507 quality of the rivers entering the lake is significant. The urban watershed has a higher COD

508 value, the phosphate mine watershed has a higher TP value, and the mountain watershed has a

509 higher TN value. The changes of COD, TN, and TP generally revealed a growing trend in each

510 sub-basin, and the variation was significant.

511 The spatial variation of LUCC in the basin is significant. With an economy focused on

512 development and the enhancement of human activities, as well as the increase of urbanization in

513 the basin, the cultivated land in sub-basins of urban areas, phosphate mines, and village farmland

514 shows a decreasing trend, while ISA and other land use are increasing, and the water area basically

515 remains the same. The woodland and grass in the phosphate basin is increasing, while it is 516 decreasing in urban areas and villages.

517 Multi-scale relationships exist between the LULC types and water quality. In the analysis of 518 the relationship between the LULC type and water quality, the spatial heterogeneity of LULC and 519 pollution sources in the basin were fully believed to affect the water quality indicators, and the 520 multi-scale relationship analysis between LULC and water quality from different pollution sources 521 within the basin was strengthened. This enhances some of the research uncertainty and highlights 
522 the multi-scale relationship between LULC changes and the water quality indicators. (1) There is 523 a significant difference in the interpretation of the relationship between water quality and LULC 524 types and patterns. The area percentage of ISA and artificial excavation land, desert, and bare 525 surface plays a promoting role in each spatiotemporal scales, while planting land and forest grass 526 cover plays an inhibitory role. Forest cover can be expected to improve the water quality. There is 527 no obvious correlation between the increase or decrease of planting land and water quality. The 528 impact of planting land on water quality is complex and negatively correlated with TN and TP. 529 This indicates that the area percentage of agricultural land is not the main factor affecting TN, but 530 is related to the application of pesticides and fertilizers, planting structure, and distance from the 531 receiving water body and topography.

532 The multi-scale relationship between the LULC types and water quality is significant. (1) The $533300 \mathrm{~m}$ riparian buffer zone in urban watersheds is the strongest spatial scale (feature scale) of the 534 LULC type effect on COD. This is consistent with the results of other plateau lake studies, and the 535 universality of this conclusion needs further verification. (2)There are similarities between the 536 effect the LULC pattern has on the water quality and the effect of the LULC type on the water 537 quality index. The urban LULC type and pattern have the greatest impact on COD, the phosphate 538 mine area has the greatest impact on TP, and the village farmland has the greatest impact on TN. 539 The difference is as follows: urban and phosphate mines have a higher interpretation of COD and 540 TP in the buffer zone of $300 \mathrm{~m}, 500 \mathrm{~m}$, and $700 \mathrm{~m}$, while in the village farmland, the sub-basin scale 541 has the highest interpretation of water quality. The influence of the LULC pattern on the water 542 quality indicators in different regions are as follows: in urban areas and phosphate mines, COD 543 and TP are better explained in sub-basin; in village farmland, TN can be better explained in $700 \mathrm{~m}$ 544 buffer zone, and TP has a higher interpretation in the buffer zone at $300 \mathrm{~m}$.

545 The regional differences in the watershed environmental protection measures are significant from 546 the perspective of preventing contamination, improving the quality of water entering the basin, 547 and referencing the water quality threshold landscape components. In the village farmland area, 548 the ISA ratio should be reduced from the current $6 \%$ to less than $5 \%$. The adjustment should be 549 most effective in the 700-meter river bank and correspondingly reduce the area of other land within 550 the riparian buffer at 1000 meters, especially artificial digs, deserts, and bare ground. The coverage 551 of forest and grass in the range of 500 meters to 1000 meters on the riparian buffer should also be 552 increased as should a focus on protecting the existing types of forest and grass cover. 
553 In the phosphate mining area, the area of other LULC types (artificial excavation, desert, and bare 554 ground) should be reduced. At the same time, the proportion of ISA should be decreased to less 555 than 5\%, reducing the area of planted land and increasing the coverage of forest and grass, 556 especially to strengthen the restoration of forest and grass cover on the phosphate rock land and 557 the land use remediation after the relocation of phosphorus chemical enterprises. According to the 558 correlation between the land bank and the water quality in the river bank in the 100-meter buffer 559 zone of the river bank, it is necessary to focus on the restoration of forest and grass cover on the 560 phosphate rock land (desert and bare ground), as well as the large amount of labor required after 561 the relocation of the phosphorus chemical enterprise. The treatment of landfill and a restoration of 562 surface cover should also be addressed. In the buffer zone of 500 meters to 700 meters, the 563 proportion of ISA is mainly reduced, and the proportion of forest and grass cover is increased at 564300 to 500 meters.

565 There is a need to refer to the results of previous studies for the urban areas (Theobald et al., 2009;

566

567

568

569

570

571

572

573

574

575

576

577

578

579

580

581

\section{References} later time.
Liu et al., 2011). The main city area is at a threshold level of degradation (48\%). Therefore, the urban area should greatly control the proportion of ISA, minimize the proportion of ISA, and increase the coverage of forest and grass. Although other land types (artificial excavation, desert and bare ground) are not related to water quality indicators, recovery also makes sense. From the sensitive scale of the river bank buffer zone, the adjustment of the above-mentioned land types is most effective in the range of 300 meters from the river bank.

With the rapid development of the regional social economy and the acceleration of urbanization, the effects on the water environment caused by the change of LULC has become a vital academic issue to address. The understanding and correlation between LULC and water quality have more commonalities, but due to the combination of regional characteristics, scale effects, and data quality (second-hand data), the research results can be unique or lead to uncertainty. Due to many factors affecting lake basins and rivers, complex interactions, and limitations in research data, time, and author level, the mechanism of LULC changes on water quality, and the monthly and seasonal equivalents of LULC types, and water quality, a multi-time-scale response will be carried out at a

Peer] reviewing PDF | (2019:03:36121:1:2:NEW 30 May 2019) 
585 Bahar MM, Ohmori H, Yamamuro M. 2008. Relationship between river water quality and 586 land use in a small river basin running through the urbanizing area of Central Japan. Limnology 587 9(1):19-26.

588 Basnyat P, Teeter LD, Flynn KM, Lockaby BG. 1999. Relationships Between Landscape 589 Characteristics and Nonpoint Source Pollution Inputs to Coastal Estuaries. Environmental 590 Management 23(4):539-549.

591 Cao C, Zhang F, Zhu SD, Guo M, Talifujiang Alimire, Hsiangte K. 2018. Relationship 592 Between Landscape Pattern and Water Quality in the Ebinur Lake Region. Environmental 593 Science 39(4): 1568-1577.

594 Chang H. 2008. Spatial analysis of water quality trends in the Han River basin, South Korea. 595 Water Research 42(13):3285-3304.

596 Chen JX, Lyu Y, Zhao ZhF, Liu H, Zhao HL, Li ZC. 2019. Using the multidimensional 597 synthesis methods with non-parameter test, multiple time scales analysis to assess water quality 598 trend and its characteristics over the past 25 years in the Fuxian Lake, China. Science of the 599 Total Environment 655:242-254.

600 Dai XY, Zhou YQ, Ma WCh, Zhou LG. 2017. Influence of spatial variation in land-use 601 patterns and topography on water quality of the rivers inflowing to fuxian lake, a large deep lake 602 in the plateau of southwestern china. Ecological Engineering 99:417-428.

603 Ding J, Jiang Y, Liu Q, Hou ZJ, Liao JY, Fu L. 2016. Influences of the land use pattern on 604 water quality in low-order streams of the Dongjiang River basin, China: A multi-scale analysis.

605 Science of the Total Environment 551-552:205-216.

606 Duan LD, Zhang HC, Ming QZ, Li HY, Zhang ZQ. 2013. Exploration and analysis about the 607 construction of eco-cities in the catchment of plateau lakes and its feasibility in Yunnan Province 608 under the view of ecological civilization. Sustainable Development (Shanghai) 3(2): 33-40.

609 Fedorko EJ, Pontius Jr RG, Aldrich SP, Claessens L, Hopkinson C Jr, Wollheim WM. 610 2005. Spatial distribution of land type in regression models of pollutant loading. Journal of 611 Spatial Hydrology 5(20):60-80.

612 Gao W, Chen Y, Guo HC. 2014. Coupled model of “assessment-simulation-optimization” for 613 basin environmental economic decision-making. Acta Scientiae Circumstantiae (1):250-258.

614 Gao W, Chen Y, Xu M, Guo HC, Xie YC. 2013. Trend and driving factors of water quality 615 change in Lake Fuxian (1980-2011). J Lake Sci 25(5):635-642. 
616 Guang BH, Li J, Zeng AB, Deng JS, Zhang J. 2008. Impacts of Urban Land Use on Water

617 Quality in Hangzhou. Resources Science 30(6): 857-863.

618 Huang JL, Li QS, Hong HS, Ling J, Qu, MC. 2011. Preliminary Study on Linking Land Use

619 \& Landscape Pattern and Water Quality in the Jiulong River Watershed. Environmental Science 620 32(1): 64-72.

621 Jarvie HP, Oguchi T, Neal C. 2002. Exploring the linkages between river water chemistry and

622 watershed characteristics using GIS-based catchment and locality analyses. Regional

623 Environmental Change 3(1-3):36-50.

624 Johnson L, Richards C, Host G, Arthur JW. 2010. Landscape influences on water chemistry 625 in Midwestern stream ecosystems. Freshwater Biology 37(1):193-208.

626 Lenat DR, Crawford JK. 1994. Effects of land use on water quality and aquatic biota of three

627 North Carolina Piedmont streams. Hydrobiologia 294(3):185-199.

628 Li S, Sheng G, Xiang T, Gu S, Tan X, Zhang QF. 2009. Water quality in the upper Han River 629 basin, China: The impacts of land use/land cover in riparian buffer zone. Journal of Hazardous 630 Materials. 165(1-3):317-324.

631 Li SH, Jin BX, Wei XY, Jiang YY, Wang JL. 2015. Using CA-Markov model to model the 632 spatiotemporal change of land use/cover in Fuxian Lake for decision support. ISPRS Annals of 633 the Photogrammetry, Remote Sensing and Spatial Information Sciences 2(4):163-169.

634 Li SH, Jin BX, Zhou JS, Wang JL, Peng SY. 2017. Analysis of the Spatiotemporal Land635 Use/Land-Cover Change and its Driving Forces in Fuxian Lake Watershed, 1974 to 2014. Polish 636 Journal of Environmental Studies 26(2):671-681.

637 Li SH, Zhou JS, Jin BX, Zhou JS, Wang JL, Peng SY. 2016. Dynamic Monitoring of

638 Fractional Vegetation Cover in Fuxian Lake Watershed Based on Multi-Temporal Landsat 5/8 639 Images. International Journal of Earth Sciences and Engineering 9(4):1596-1601.

640 Li W, Fu H, Cao T, Zhang XL, Zhong JY, Ni LY, Xie P, Fan HB. 2017. Distribution and 641 carbon,nitrogen and phosphorus stoichiometric characteristics of submersed macrophytes in 642 Lake Fuxian. Journal of Lake Sciences 29(2):448-457.

643 Li XR, Li YB, Shao JA. 2016. A study on the response of non-point source pollution to the 644 variation of land use and social economy. Acta Ecologica Sinica 36(19):6050-6061.

645 Li YL, Xu ZX, Li YF. 2012. A Preliminary Study on the Relationship Between Multi-scale 646 Land Use \& Landscape and River Water Quality Response in the Huntai Watershed. Earth and 647 Environment 40(4): 573-583.

648 Li YX, Liu H, Lu Y, Wang L. 2003. Preliminary studies on eutrophication in Fuxian 649 Lake.Journal of Lake sciences 15(3):285-288. 
650 Li YX, Wang L, Qi YK. Tang F. 2007. Studies on the phytoplankton development trend in 651 Lake Fuxian, China. Journal of Lake sciences 19(2):223-226.

652 Liu Y, Wu G, Gao ZW. 2008. Impacts of land-use change in Fuxian and Qilu basins of Yunnan

653 Province on lake water quality. Chinese Journal of Ecology 27(3):447-453.

654 Liu Y, Wu G, Gao ZW. 2018. Impacts of land-use change in Fuxian and Qilu basins of Yunnan 655 Province on lake water quality. Chinese Journal of Ecology 27(3): 447-453.

656 Lopez RD, Nash MS, Heggem DT, Ebert DW. 2008. Watershed vulnerability predictions for

657

658 the Ozarks using landscape models. - Journal of Environmental Quality 37(5):1769-1780

659 Ma LC, Wang JL, Li SH, Zhou JS, Jin BX. 2016. Remote Sensing Monitoring of Soil Erosion

660 Meneses BM, Reis R, Vale MJ, Saraiva R. 2015. Land use and land cover changes in Zêzere in Fuxianhu Lake Basin. Research of Soil and Water Conservation 23(3):65-70.

661 watershed (Portugal)--Water quality implications. Science of the Total Environment S527-

662 528:439-447.

663 Novotny V. 2002. Water quality: diffuse pollution and watershed management. (2 nd edition) -

664 New York: John wiley \& sons,Inc.76-77

665 Osborne LL, Wiley MJ. 1988. Empirical Relationships Between Land Use/Cover and Stream 666 Water Quality in Agricultural Watersheds. Journal of Environmental Management 26(1):9-27.

667 Ou Y, Wang XY, Geng RZ. 2012. The influences of different landscape characteristics on 668 water quality in the upper watershed of Miyun Reservoir. Acta Scientiae Circumstantiae 32(5): 669 1219-1226.

670 Pan JZ, Xiong F, Li WC, Li YN. 2008. Spatial-temporal dynamic changes of the water 671 transparency and their influencing factors in Lake Fuxian, Yunnan Province. Journal of Lake 672 Sciences 20(5):681-686.

673 Peng Y, Xiang S, Chu SS, Xue LQ, Ye BB. 2015. Relationship Between Agricultural Land and 674 Water Quality of Inflow River in Erhai Lake Basin. Environmental Science 36(11):4005-4012.

675 Putro B, Kjeldsen TR, Hutchins MG, Miller J. 2016. An empirical investigation of climate 676 and land-use effects on water quantity and quality in two urbanising catchments in the southern 677 United Kingdom. Science of the Total Environment 548-549:164-172.

678 Sahu M, Gu RR. 2009. Modeling the effects of riparian buffer zone and contour strips on 679 stream water quality. Ecological Engineering 35(8):1167-1177.

680 Sajikumar N, Remya RS. 2015. Impact of land cover and land use change on runoff 681 characteristics.[J]. Journal of Environmental Management 161:460-468.

682 Shen Z, Hou X, Li W, Aini GZ, Chen L, Gong YW. 2015. Impact of landscape pattern at 683 multiple spatial scales on water quality: A case study in a typical urbanised watershed in China.

684 Ecological Indicators 48(48):417-427. 
685 Sliva L, Williams DD. 2001. Buffer zone versus whole catchment approaches to studying land 686 use impact on river water quality. Water Research 35(14): 3462-3472.

687 Thomas ARC, Bond AJ. 2013. Hiscock K M. A multi-criteria based review of models that 688 predict environmental impacts of land use-change for perennial energy crops on water, carbon 689 and nitrogen cycling. GCB Bioenergy 5(3): 227-242.

690 Tu J. 2011. Spatially varying relationships between land use and water quality across an 691 urbanization gradient explored by geographically weighted regression. Applied Geography 692 31(1): 376-392.

693 Tudesque L, Tisseuil C, Lek S. 2014. Scale-dependent effects of land cover on water physico694 chemistry and diatom-based metrics in a major river system, the Adour-Garonne basin (South 695 Western France). Science of the Total Environment 466-467(1):47-55.

696 Woli KP, Nagumo T, Kuramochi K, Hatano R. 2004. Evaluating river water quality through 697 land use analysis and $\mathrm{N}$ budget approaches in livestock farming areas. Science of the Total 698 Environment 329(1-3):61-74.

699 Wu XF, Liu CM, Wang CM. 2003. Effect of horizontal resolution of raster DEM on drainage 700 basin characteristics. Journal of Natural Resources 18(2):148-154.

701 Xia TX, Li WC, Xiong F. 2007. Submerged macrophytes distribution and water body nutrient 702 contents in different type littoral zones of Fuxian Lake. Chin J Ecol 26(6):846-852.

703 Xia XF, Gu Y, Xi BD, Xu GJ. 2010. Research on agricultural structure regulation in Fuxian 704 lake basin based on water environment constraints. Research of Environmental Sciences 23(10): 705 1274-1278.

706

Xiang S, Peng Y, Dou JS, Lu XJ, Xue LQ, Chu ZS. 2018. Impact of land use on the water

707 quality of inflow river to Erhai Lake at different temporal and spatial scales. Acta Ecologica

708 Sinica 38(3):876-885.

709 Xiong F, Li WC, Pan JZ, Xia TX, Li AQ. 2006. Distribution and community structure

710 characteristics of submerged macrophytes in Lake Fuxian, Yunnan Province. Acta Botanica

711 Yunnanica 28(3):277-282.

712 Xu J, Lo SL, Gong R, Sun XX. 2016. Control of agricultural non-point source pollution in 713 Fuxian lake with riparian wetlands. Desalination and Water Treatment 57(59):28570-28580.

714 Yan T, Liu EF, Zhang EL, Li YL, Shen J. 2016. The spatio-temporal variations of heavy 715 metals in the sediment of Lake Fuxian and the contamination assessment. J Lake Sci 28(1):5071658. 
717 Yang C, Wang JL. Li SH, Wang LX, Ma LC, Pan JY, Gao F, Liu GJ. 2016. Land

718 Degradation Dynamic Remote Sensing Monitoring of Fuxian Lake Basin. Remote Sensing

719 Technology and Application 31(2):388-396.

720 Yang J, Xu YP, Gao B, Wang YF, Xu Y, Ma Q. 2017. River water quality change and its

721 relationship with landscape pattern under the urbanization: A case study of Suzhou City in Taihu

722 Basin. Journal of Lake Sciences 29(4):827-835.

723 Yang YN, Wang JL, Cheng GJ, Xi XH, Wang C. 2015. Relationship between land use pattern

724 and water quality change in Fuxian Lake basin. Remote Sensing for Land \& Resources

725 28(1):159-165.

726 Yao B, Liu QQ, Hu CM, Xi BD, Wu XH. 2017. Distribution characteristics of phosphorus in

727 the water of Lake Fuxian and its influencing factors. Science \& Technology Review 35(3):66-

72871.

729 Yu X, Hawleyhoward J, Pitt A L, Wang JJ, Baldwin RF, Chow AT. 2015. Water quality of

730 small seasonal wetlands in the Piedmont ecoregion, South Carolina, USA: Effects of land use

731 and hydrological connectivity. Water Research 73:98-108.

732 Zeng LX, Huang ZL, Xiao WF, Tian YW. 2012. Nitrogen and Phosphorus Loss in Different

733 Land Use Types and Its Response to Environmental Factors in the Three Gorges Reservoir Area.

734 Environmental Science 33(10):3390-3396.

735 Zhai ZN, Wang KQ, Su B, Guo LM. 2015. Study on water quality change in the Jianshan River 736 of Fuxian Lake watershed. Ecological Science 34(2):129-135.

737 Zhang R, Su J, Huo, SL, Chen YQ, Ji DF, Wang Y, Lv NQ. 2012. The trophic status

738 evaluation and development of nutrient water quality standards for Fuxian Lake. Journal of

739 Environmental Engineering Technology 2(3):218-222.

740 Zhang YJ, Cheng S, Xiang JC. 2011. Correlation Between the water quality and land use

741 composition in the river side area-A case of chaohu lake basin in china. Resources and

742 Environment in the Yangtze Basin 20 (9):1054-1061.

743 Zhang YY, Xie MP, Liu SS, Li HY, Duan LC. 2015. The analysis of water quality change

744 trend for Lake Fuxian \& Lake Xingyun. Geographical Science Research 4(3):81-94.

745 Zhou P, Huang J, Jr PR, Hong HS. 2016. New insight into the correlations between land use

746 and water quality in a coastal watershed of China: Does point source pollution weaken it?

747 Science of the Total Environment 543(Pt A):591. 
748 Zhou W, Liu MS, Xu C, He G, Wang L, Yang XJ. 2012. Response of river water quality to 749 background characteristics of landscapes in Taihu Lake basin. Acta Ecologica Sinica 32(16): 750 5043-5053.

751 Zhu Q, Tian YX, Zhang YT. 2005. The Extraction of Catchment and Subcatchment from

752 Regular Grid DEMs. Acta Geodaetica et Cartographica Sinica 34(2):129-133.

753

754 
Figure 1

Location of Fuxian lake watershed

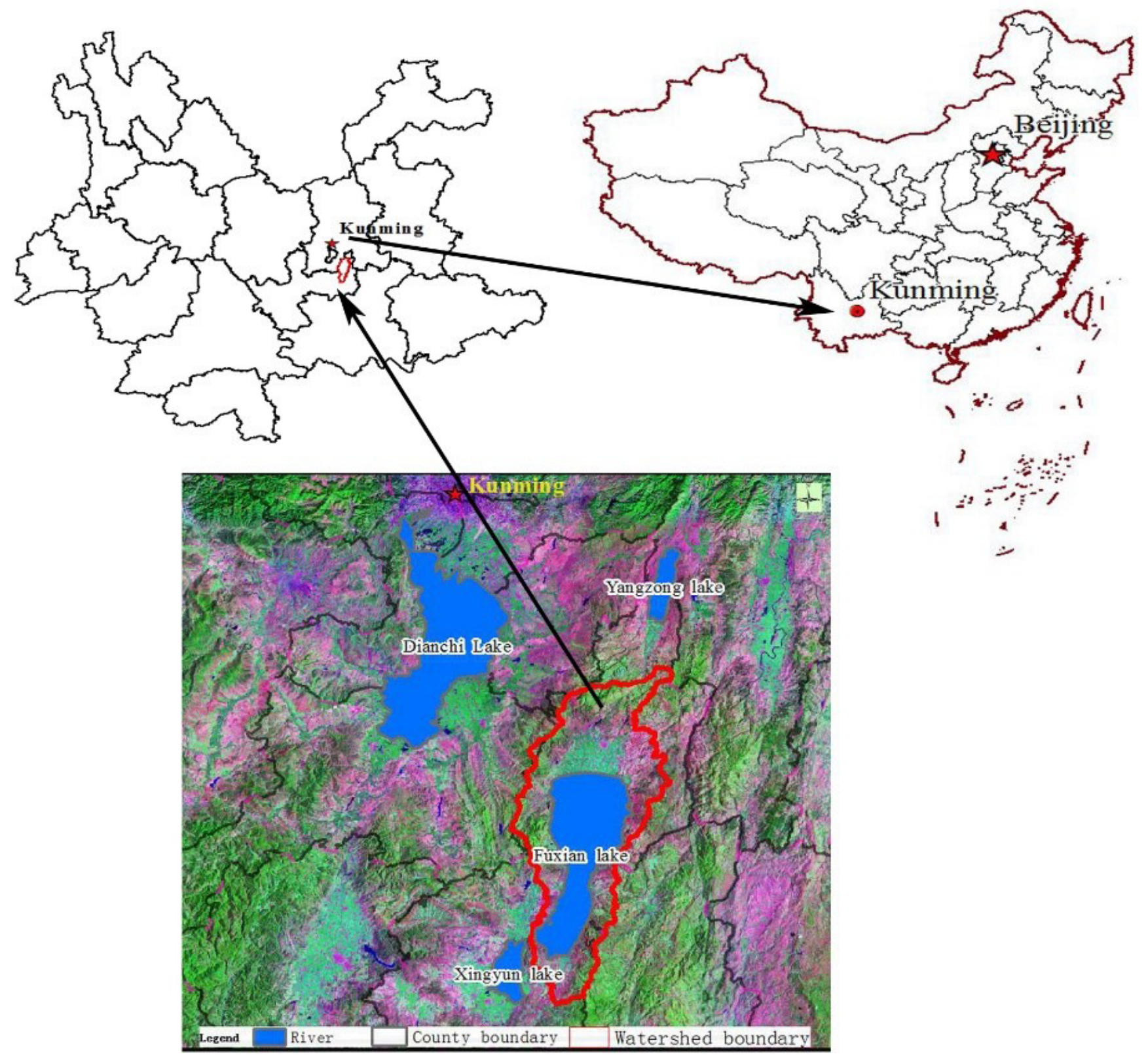


Figure 2

Remote sensing image of study area
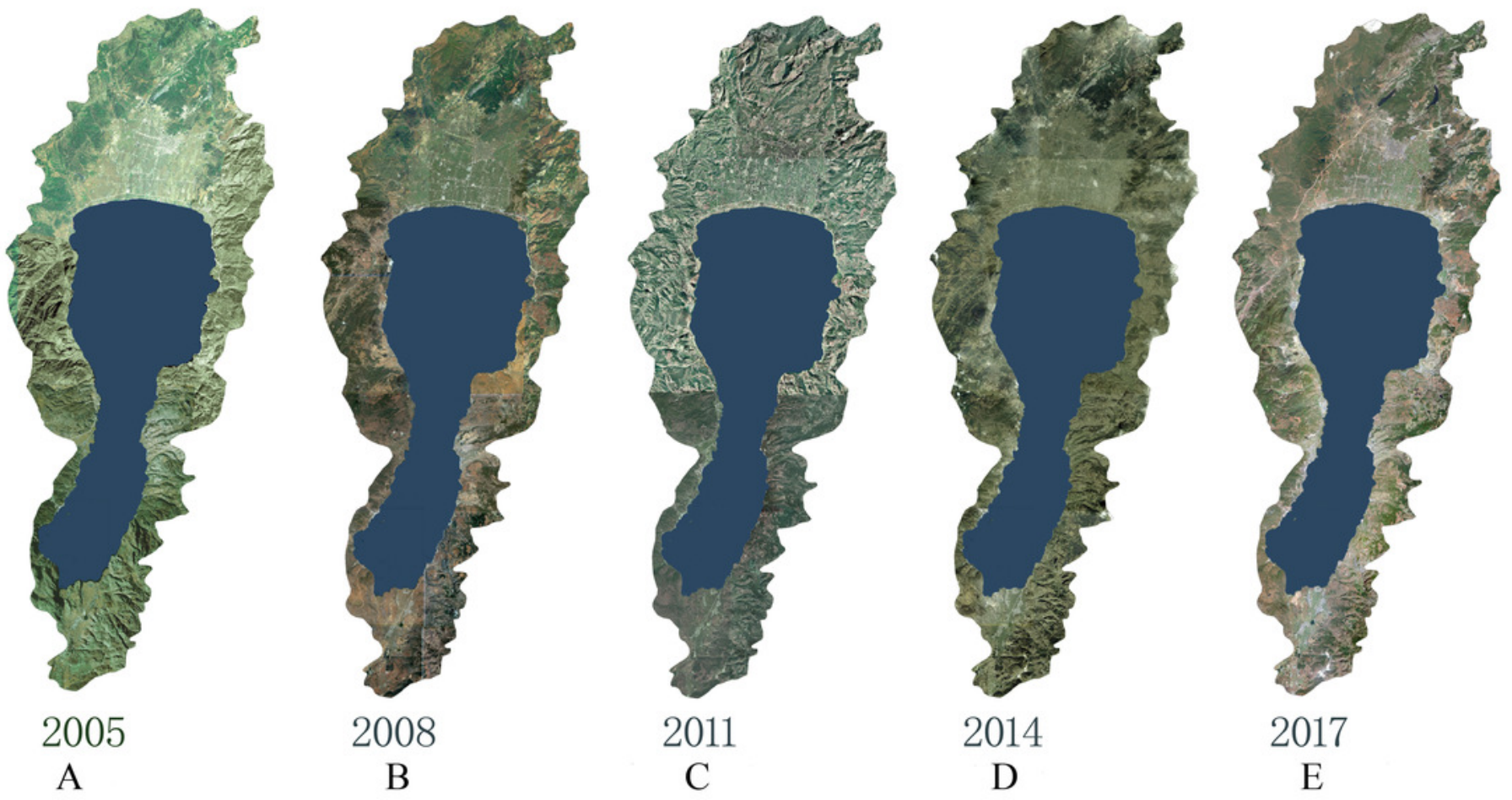
Figure 3

LULC type of study area
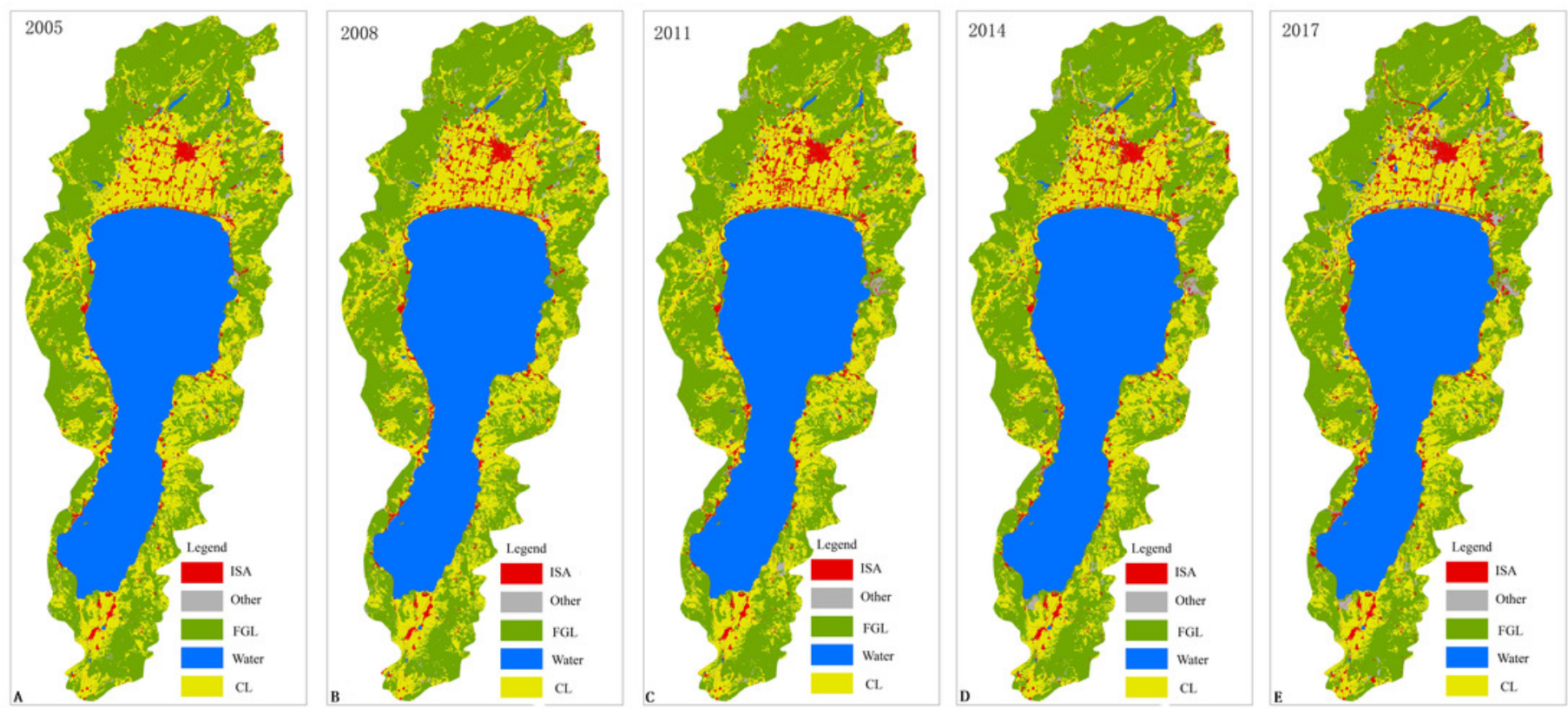
Figure 4

\section{Spatial scale of study}
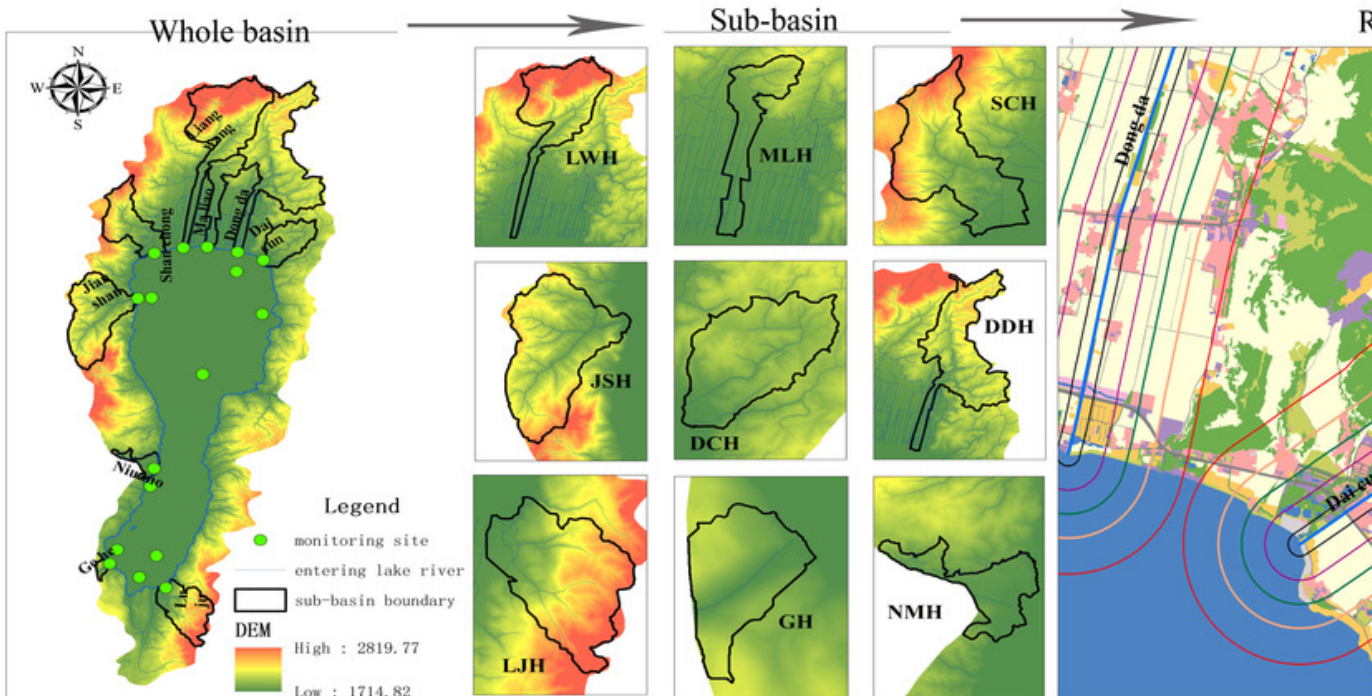

River buffer
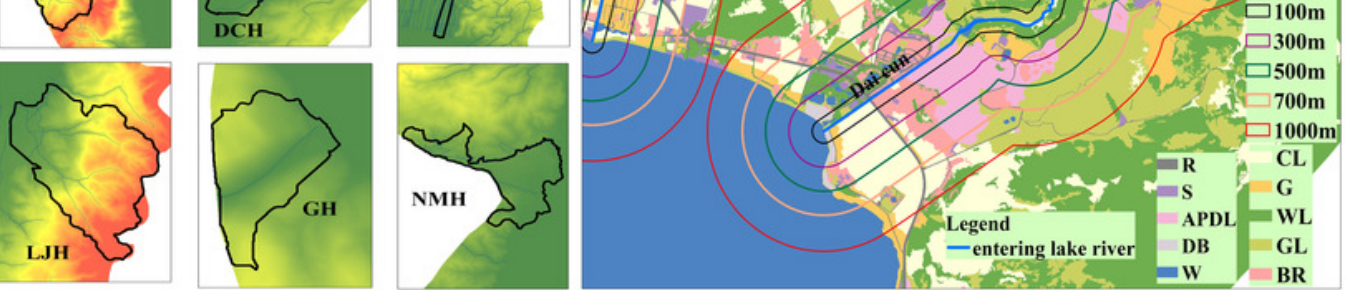


\section{Table 1 (on next page)}

Lake center and river water quality statistics 
1

\begin{tabular}{|c|c|c|c|c|c|c|c|}
\hline site & $\begin{array}{l}\text { Water } \\
\text { quality } \\
\text { index }\end{array}$ & $\begin{array}{l}\text { sample } \\
\text { s }\end{array}$ & $\begin{array}{l}\text { Minimu } \\
\text { m } \\
(\mathrm{mg} / \mathrm{L})\end{array}$ & $\begin{array}{l}\text { Maximum } \\
(\mathrm{mg} / \mathrm{L})\end{array}$ & $\begin{array}{l}\text { average } \\
(\mathrm{mg} / \mathrm{L})\end{array}$ & $\begin{array}{l}\text { Standar } \\
\text { d } \\
\text { deviatio } \\
\text { n } \\
(\mathrm{mg} / \mathrm{L})\end{array}$ & $\begin{array}{l}\text { variance } \\
(\mathrm{mg} / \mathrm{L})\end{array}$ \\
\hline \multirow{4}{*}{$\begin{array}{c}\text { River } \\
\text { entering } \\
\text { lake }\end{array}$} & COD & 45 & 1.10 & 100.17 & 20.76 & 20.67 & 426.87 \\
\hline & $\mathrm{TP}$ & 45 & 0.025 & 2.54 & 0.32 & 0.43 & 0.19 \\
\hline & $\mathrm{TN}$ & 45 & 0.322 & 32.91 & 7.75 & 7.18 & 51.49 \\
\hline & COD & 5 & 1.03 & 1.44 & 1.206 & 0.195 & 0.038 \\
\hline \multirow[t]{2}{*}{ Lake center } & $\mathrm{TP}$ & 5 & 0.001 & 0.007 & 0.004 & 0.002 & $8.00 \mathrm{E}-06$ \\
\hline & $\mathrm{TN}$ & 5 & 0.155 & 0.177 & 0.166 & 0.009 & $8.00 \mathrm{E}-05$ \\
\hline
\end{tabular}

Tab. 1 lake center and river water quality statistics

2 
Table 2 (on next page)

LULC variation characteristics in different pollution source areas 
1

2

3

\begin{tabular}{|c|c|c|c|c|c|c|}
\hline LULC types & Scale & 2005 & 2008 & 2011 & 2014 & 2017 \\
\hline \multirow{4}{*}{$\begin{array}{l}\text { cropping } \\
\text { land }\end{array}$} & phosphate mine basin & 35.52 & 34.86 & 33.61 & 31.31 & 30.65 \\
\hline & urban & 52.51 & 49.20 & 46.91 & 45.92 & 41.30 \\
\hline & $\begin{array}{l}\text { Village and farmland } \\
\text { basin }\end{array}$ & 26.10 & 25.77 & 24.62 & 24.09 & 23.53 \\
\hline & Whole basin & 23.96 & 23.48 & 22.47 & 21.93 & 21.63 \\
\hline \multirow{4}{*}{$\begin{array}{l}\text { forestry and } \\
\text { grass cover }\end{array}$} & phosphate mine basin & 57.09 & 57.03 & 58.08 & 58.54 & 56.84 \\
\hline & urban & 29.15 & 29.21 & 29.95 & 32.19 & 31.37 \\
\hline & $\begin{array}{l}\text { Village and farmland } \\
\text { basin }\end{array}$ & 69.01 & 68.71 & 70.10 & 70.51 & 69.74 \\
\hline & Whole basin & 39.68 & 39.79 & 40.34 & 40.6 & 39.85 \\
\hline \multirow{4}{*}{$\begin{array}{l}\text { impervious } \\
\text { surface area }\end{array}$} & phosphate mine basin & 4.06 & 4.25 & 4.93 & 4.95 & 5.78 \\
\hline & urban & 16.87 & 20.02 & 21.66 & 19.02 & 19.09 \\
\hline & $\begin{array}{l}\text { Village and farmland } \\
\text { basin }\end{array}$ & 3.61 & 4.10 & 4.41 & 4.06 & 4.76 \\
\hline & Whole basin & 3.35 & 3.66 & 4.13 & 3.95 & 4.4 \\
\hline \multirow[t]{4}{*}{ other land } & phosphate mine basin & 1.75 & 2.32 & 2.06 & 3.73 & 5.26 \\
\hline & urban & 0.20 & 0.55 & 0.73 & 1.61 & 6.78 \\
\hline & $\begin{array}{l}\text { Village and farmland } \\
\text { basin }\end{array}$ & 0.10 & 0.42 & 0.13 & 0.26 & 0.75 \\
\hline & Whole basin & 0.48 & 0.62 & 0.82 & 1.19 & 1.68 \\
\hline \multirow[t]{4}{*}{ water } & phosphate mine basin & 1.57 & 1.54 & 1.33 & 1.47 & 1.47 \\
\hline & urban & 1.28 & 1.01 & 0.75 & 1.26 & 1.46 \\
\hline & $\begin{array}{l}\text { Village and farmland } \\
\text { basin }\end{array}$ & 1.18 & 1.00 & 0.75 & 1.08 & 1.21 \\
\hline & Whole basin & 32.53 & 32.45 & 32.24 & 32.33 & 32.44 \\
\hline
\end{tabular}




\section{Table 3 (on next page)}

Multi-scale relationship analysis between LULC type and water quality 
Tab. 3 Correlation between LULC type and water quality

\begin{tabular}{|l|l|l|l|l|l|l|}
\hline Scale & $\begin{array}{l}\text { Water } \\
\text { quality index }\end{array}$ & CL & FGL & ISA & Othl & Water \\
\hline \multirow{3}{*}{$\begin{array}{l}\text { Whole } \\
\text { basin }\end{array}$} & COD & -0.794 & 0.272 & 0.612 & $0.901^{*}$ & -0.008 \\
\cline { 2 - 7 } & TP & $0.941^{*}$ & -0.532 & 0.769 & $0.933^{*}$ & -0.327 \\
\cline { 2 - 7 } & TN & -0.444 & -0.159 & 0.722 & 0.491 & -0.228 \\
\hline \multirow{4}{*}{ urban } & COD & $-0.994^{* *}$ & $-0.949^{*}$ & $0.975^{* *}$ & 0.823 & 0.255 \\
\cline { 2 - 7 } & TP & -0.473 & -0.692 & 0.405 & 0.048 & -0.558 \\
\cline { 2 - 7 } & TN & -0.187 & -0.543 & 0.174 & -0.087 & 0.106 \\
\hline \multirow{2}{*}{$\begin{array}{c}\text { phosphate } \\
\text { mine basin }\end{array}$} & COD & 0.532 & -0.118 & 0.620 & $0.848^{* *}$ & -.0275 \\
\cline { 2 - 7 } & TP & $0.924^{* *}$ & -0.406 & $0.925^{* *}$ & $0.821^{* *}$ & -.0622 \\
\cline { 2 - 7 } & TN & 0.477 & 0.078 & 0.538 & 0.427 & -.0158 \\
\hline \multirow{2}{*}{$\begin{array}{l}\text { Village and } \\
\text { farmland } \\
\text { basin }\end{array}$} & COD & -0.784 & -0.626 & 0.753 & 0.774 & -0.093 \\
\cline { 2 - 7 } & TP & $-0.955^{*}$ & $-0.922^{*}$ & $0.892^{*}$ & 0.810 & -0.403 \\
\cline { 2 - 7 } & TN & $-0.986^{* *}$ & $-0.966^{* *}$ & $0.929^{*}$ & 0.797 & -0.600 \\
\hline
\end{tabular}

2 


\section{Table 4 (on next page)}

Relationship model between LULC types and water quality in watershed scale 
1 Tab. 4 Relationship model between water quality of entering lake river and LULC type at sub-

2 basin scale

\begin{tabular}{|c|c|c|c|c|c|}
\hline Scale & $\begin{array}{l}\text { Water } \\
\text { quality } \\
\text { index }\end{array}$ & Regression equation & $\mathrm{R}^{2}$ & $\begin{array}{c}\text { Adjusted } \\
\mathrm{R}^{2}\end{array}$ & Sig. \\
\hline \multirow{3}{*}{ Urban basin } & COD & $\mathrm{COD}=99.199-1.733$ FarmL & 0.988 & 0.984 & 0.001 \\
\hline & $\mathrm{TP}$ & Variable removed & - & - & - \\
\hline & $\mathrm{TN}$ & Variable removed & - & - & - \\
\hline \multirow{3}{*}{$\begin{array}{l}\text { phosphate } \\
\text { mine basin }\end{array}$} & COD & $\mathrm{COD}=-19.68+12.27 \mathrm{OthL}$ & 0.719 & 0.684 & 0.002 \\
\hline & $\mathrm{TP}$ & $\mathrm{TP}=-0.44+0.089 \mathrm{ISA}+0.061 \mathrm{OthL}$ & 0.950 & 0.936 & 0.000 \\
\hline & $\mathrm{TN}$ & Variable removed & - & - & - \\
\hline \multirow{3}{*}{$\begin{array}{l}\text { Village and } \\
\text { farmland } \\
\text { basin }\end{array}$} & COD & Variable removed & - & - & - \\
\hline & $\mathrm{TP}$ & $\mathrm{TP}=2.525-0.104 \mathrm{FarmL}$ & 0.912 & 0.883 & 0.11 \\
\hline & $\mathrm{TN}$ & $\mathrm{TN}=78.632-3.171 \mathrm{FarmL}$ & 0.973 & 0.964 & 0.02 \\
\hline \multirow{3}{*}{ Whole basin } & COD & $\mathrm{COD}=0.857+0.901 \mathrm{OthL}$ & 0.811 & 0.749 & 0.037 \\
\hline & $\mathrm{TP}$ & $\mathrm{TP}=-0.057+0.941$ FarmL & 0.886 & 0.848 & 0.017 \\
\hline & $\mathrm{TN}$ & Variable removed & - & - & - \\
\hline
\end{tabular}

3 


\section{Table 5 (on next page)}

Multi-scale correlationship between LULC types and water quality in different pollution source areas 
Tab. 4 Correlation between water quality and LULC in different pollution source areas

\begin{tabular}{|c|c|c|c|c|c|}
\hline Scale & LULC type & $\begin{array}{l}\text { Riparian buffer } \\
\text { (meters) }\end{array}$ & $\begin{array}{l}\mathrm{COD} \\
(\mathrm{mg} / \mathrm{L})\end{array}$ & $\begin{array}{l}\mathrm{TP} \\
(\mathrm{mg} / \mathrm{L})\end{array}$ & $\begin{array}{l}\mathrm{TN} \\
(\mathrm{mg} / \mathrm{L})\end{array}$ \\
\hline \multirow{25}{*}{$\begin{array}{l}\text { Urban } \\
\text { basin }\end{array}$} & \multirow{5}{*}{$\mathrm{CL}$} & 100 & $-0.939^{*}$ & -0.491 & -0.539 \\
\hline & & 300 & $-0.992^{* *}$ & -0.631 & -0.314 \\
\hline & & 500 & $-0.999^{* *}$ & -0.538 & -0.292 \\
\hline & & 700 & $-0.990^{* *}$ & -0.498 & -0.327 \\
\hline & & 1000 & $-0.978^{* *}$ & -0.466 & -0.320 \\
\hline & \multirow{5}{*}{ FGL } & 100 & -0.816 & -0.288 & -0.625 \\
\hline & & 300 & -0.703 & -0.258 & -0.748 \\
\hline & & 500 & -0.717 & -0.371 & -0.798 \\
\hline & & 700 & -0.775 & -0.437 & -0.771 \\
\hline & & 1000 & -0.798 & -0.419 & -0.720 \\
\hline & \multirow{5}{*}{ ISA } & 100 & -0.341 & 0.339 & -0.372 \\
\hline & & 300 & 0.277 & 0.757 & -0.084 \\
\hline & & 500 & 0.463 & 0.849 & 0.085 \\
\hline & & 700 & 0.618 & $0.914^{*}$ & 0.197 \\
\hline & & 1000 & 0.827 & 0.877 & 0.203 \\
\hline & \multirow{5}{*}{ Othl } & 100 & 0.839 & 0.171 & 0.449 \\
\hline & & 300 & $0.894^{*}$ & 0.192 & 0.107 \\
\hline & & 500 & 0.854 & 0.107 & -0.008 \\
\hline & & 700 & 0.849 & 0.094 & -0.028 \\
\hline & & 1000 & 0.862 & 0.109 & 0.052 \\
\hline & \multirow{5}{*}{ Water } & 100 & 0.393 & -0.414 & 0.701 \\
\hline & & 300 & 0.283 & -0.486 & 0.192 \\
\hline & & 500 & 0.414 & -0.402 & 0.114 \\
\hline & & 700 & 0.497 & -0.389 & 0.075 \\
\hline & & 1000 & 0.545 & -0.343 & -0.018 \\
\hline \multirow{11}{*}{$\begin{array}{l}\text { phosphate } \\
\text { mine } \\
\text { basin }\end{array}$} & \multirow{5}{*}{$\mathrm{CL}$} & 100 & -0.443 & $-0.777 * *$ & -0.531 \\
\hline & & 300 & -0.573 & $-0.882 * *$ & $-0.643^{*}$ \\
\hline & & 500 & -0.612 & $-0.871 * *$ & -0.625 \\
\hline & & 700 & -0.572 & $-0.755^{*}$ & -0.579 \\
\hline & & 1000 & -0.434 & -0.499 & -0.477 \\
\hline & \multirow{5}{*}{ FGL } & 100 & -0.283 & $-0.665^{*}$ & -0.327 \\
\hline & & 300 & -0.267 & $-0.718 *$ & -0.378 \\
\hline & & 500 & -0.303 & $-0.727^{*}$ & -0.519 \\
\hline & & 700 & -0.315 & $-0.670 *$ & -0.497 \\
\hline & & 1000 & -0.389 & $-0.689 *$ & -0.472 \\
\hline & ISA & 100 & 0.109 & 0.549 & 0.324 \\
\hline
\end{tabular}




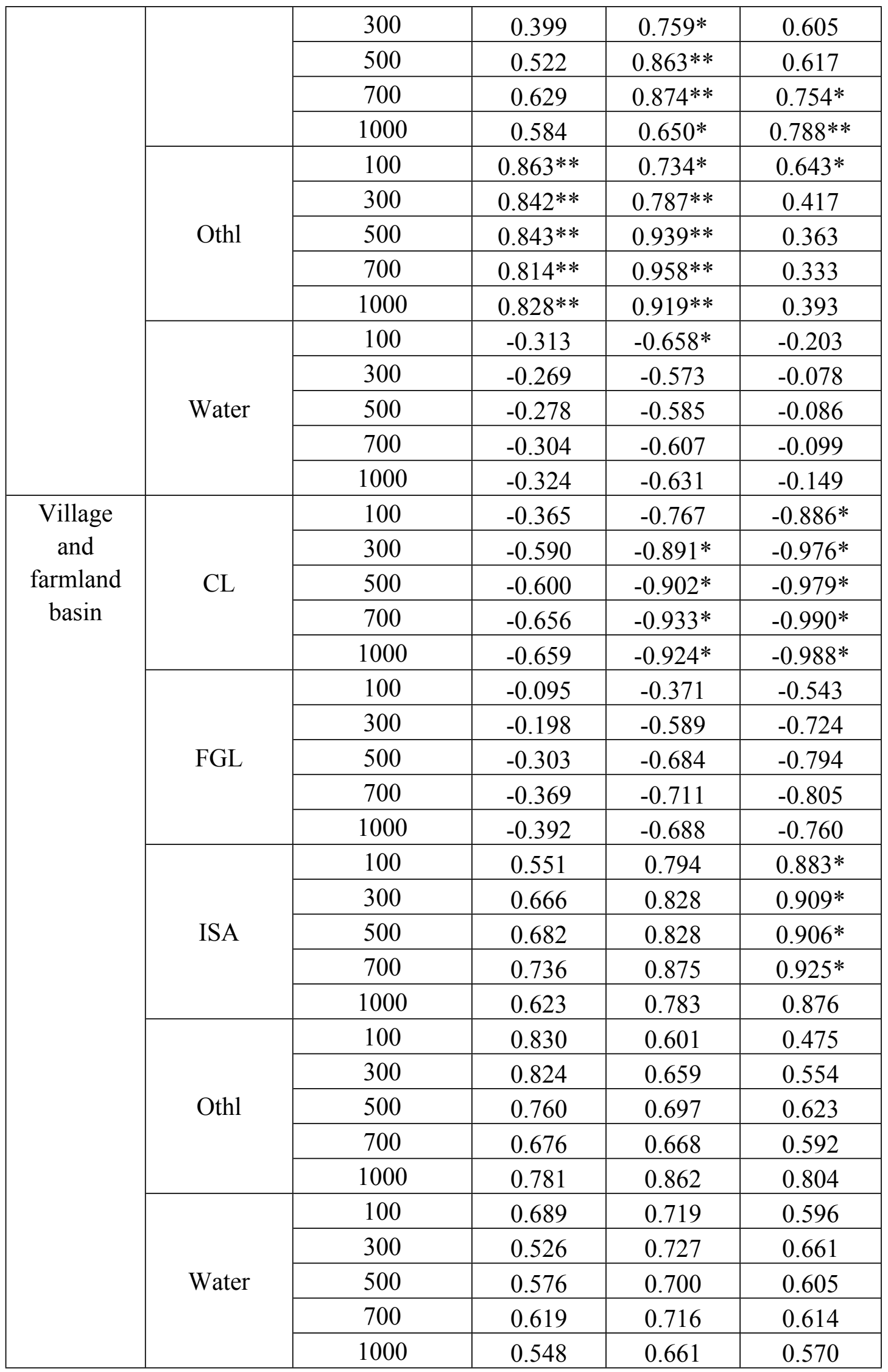


Table 6(on next page)

Multi-scale relationship model of LULC types for water quality in different pollution source areas 
1 Tab. 6 Multi-scale relationship model of LULC type for water quality in different pollution source 2 areas

\begin{tabular}{|c|c|c|c|c|c|c|}
\hline $\begin{array}{l}\text { Spatial } \\
\text { scale }\end{array}$ & buffer & $\begin{array}{l}\text { Water } \\
\text { quality } \\
\text { index }\end{array}$ & Regression equation & $\mathrm{R}^{2}$ & $\begin{array}{l}\text { Adjusted } \\
\qquad \mathrm{R}^{2}\end{array}$ & Sig. \\
\hline \multirow[t]{15}{*}{ urban } & \multirow{3}{*}{$100 \mathrm{~m}$} & COD & $\mathrm{COD}=80.589-1.562$ FarmL & $\begin{array}{c}0.88 \\
1\end{array}$ & 0.841 & $\begin{array}{c}0.01 \\
8\end{array}$ \\
\hline & & $\mathrm{TP}$ & Variable removed & - & - & - \\
\hline & & $\mathrm{TN}$ & Variable removed & - & - & - \\
\hline & \multirow{3}{*}{$300 \mathrm{~m}$} & COD & $\begin{array}{l}\mathrm{COD}=96.942- \\
1.453 \text { FarmL }+0.7120 \text { thL }\end{array}$ & 1.0 & 1.0 & $\begin{array}{c}0.00 \\
0\end{array}$ \\
\hline & & $\mathrm{TP}$ & Variable removed & - & - & - \\
\hline & & $\mathrm{TN}$ & Variable removed & - & - & - \\
\hline & \multirow{3}{*}{$500 \mathrm{~m}$} & COD & $\mathrm{COD}=96.819-1.677$ FarmL & $\begin{array}{c}0.99 \\
9\end{array}$ & 0.998 & $\begin{array}{c}0.00 \\
0\end{array}$ \\
\hline & & $\mathrm{TP}$ & Variable removed & - & - & - \\
\hline & & $\mathrm{TN}$ & Variable removed & - & - & - \\
\hline & \multirow{3}{*}{$700 \mathrm{~m}$} & COD & $\mathrm{COD}=91.237-1.505$ FarmL & $\begin{array}{c}0.98 \\
1\end{array}$ & 0.975 & $\begin{array}{c}0.00 \\
1\end{array}$ \\
\hline & & $\mathrm{TP}$ & $\mathrm{TP}=-1.657+0.088 \mathrm{ISA}$ & $\begin{array}{c}0.83 \\
5\end{array}$ & 0.780 & $\begin{array}{c}0.03 \\
0\end{array}$ \\
\hline & & $\mathrm{TN}$ & Variable removed & - & - & - \\
\hline & \multirow{3}{*}{$1000 \mathrm{~m}$} & COD & $\mathrm{COD}=89.959-1.485$ FarmL & $\begin{array}{c}0.95 \\
7\end{array}$ & 0.942 & $\begin{array}{c}0.00 \\
4\end{array}$ \\
\hline & & $\mathrm{TP}$ & Variable removed & - & - & - \\
\hline & & $\mathrm{TN}$ & Variable removed & - & - & - \\
\hline Phosphate & $100 \mathrm{~m}$ & COD & $\mathrm{COD}=-0.201+10.676$ othL & 0.74 & 0.712 & 0.00 \\
\hline
\end{tabular}




\begin{tabular}{|c|c|c|c|c|c|c|}
\hline \multirow{3}{*}{\multicolumn{2}{|c|}{ mining area }} & & & 4 & & 1 \\
\hline & & $\mathrm{TP}$ & $\mathrm{TP}=1.372-0.029 \mathrm{FarmL}$ & $\begin{array}{c}0.60 \\
4\end{array}$ & 0.554 & 0.08 \\
\hline & & $\mathrm{TN}$ & $\mathrm{TN}=3.089+1.167 \mathrm{othL}$ & $\begin{array}{c}0.41 \\
3\end{array}$ & 0.340 & 0.45 \\
\hline & \multirow{3}{*}{$300 \mathrm{~m}$} & COD & $\begin{array}{l}\mathrm{COD}=- \\
29.907+11.726 \text { othL }+4.495 \text { Water }\end{array}$ & $\begin{array}{c}0.87 \\
8\end{array}$ & 0.843 & 0.01 \\
\hline & & $\mathrm{TP}$ & $\mathrm{TP}=1.118-0.029$ FarmL +0.043 othL & $\begin{array}{c}0.89 \\
3\end{array}$ & 0.862 & 0.00 \\
\hline & & $\mathrm{TN}$ & $\mathrm{TN}=18.767-0.395 \mathrm{FarmL}$ & $\begin{array}{c}0.41 \\
4\end{array}$ & 0.341 & $\begin{array}{c}0.04 \\
5\end{array}$ \\
\hline & \multirow{3}{*}{$500 \mathrm{~m}$} & COD & $\begin{array}{l}\mathrm{COD}=- \\
29.745+11.223 \text { othL }+5.198 \text { Water }\end{array}$ & $\begin{array}{c}0.86 \\
0\end{array}$ & 0.820 & $\begin{array}{c}0.00 \\
1\end{array}$ \\
\hline & & $\mathrm{TP}$ & $\mathrm{TP}=0.844+0.065$ othL -0.021 FarmL & $\begin{array}{c}0.99 \\
0\end{array}$ & 0.987 & 0.00 \\
\hline & & $\mathrm{TN}$ & Variable removed & - & - & - \\
\hline & \multirow{3}{*}{$700 \mathrm{~m}$} & COD & $\mathrm{COD}=-2.252+8.166$ othL & $\begin{array}{c}0.66 \\
3\end{array}$ & 0.621 & 0.04 \\
\hline & & $\mathrm{TP}$ & $\mathrm{TP}=-0.542+0.073$ othL $+0.8 \mathrm{ISA}$ & $\begin{array}{c}0.99 \\
7\end{array}$ & 0.996 & 0.00 \\
\hline & & $\mathrm{TN}$ & $\mathrm{TN}=-10.207+2.091 \mathrm{ISA}$ & $\begin{array}{c}0.56 \\
8\end{array}$ & 0.514 & $\begin{array}{c}0.01 \\
2\end{array}$ \\
\hline & \multirow{3}{*}{$1000 \mathrm{~m}$} & COD & $\mathrm{COD}=-10.61+12.501 \mathrm{othL}$ & $\begin{array}{c}0.68 \\
5\end{array}$ & 0.646 & $\begin{array}{c}0.00 \\
3\end{array}$ \\
\hline & & $\mathrm{TP}$ & $\mathrm{TP}=-0.11+0.148 \mathrm{othL}$ & $\begin{array}{c}0.84 \\
5\end{array}$ & 0.825 & $\begin{array}{c}0.00 \\
0\end{array}$ \\
\hline & & $\mathrm{TN}$ & $\mathrm{TN}=-19.188+3.269 \mathrm{ISA}$ & 0.62 & 0.573 & 0.07 \\
\hline
\end{tabular}




\begin{tabular}{|c|c|c|c|c|c|c|}
\hline & & & & 1 & & \\
\hline \multirow{15}{*}{$\begin{array}{l}\text { Village and } \\
\text { farmland }\end{array}$} & \multirow{3}{*}{$100 \mathrm{~m}$} & COD & Variable removed & - & - & - \\
\hline & & TP & Variable removed & - & - & - \\
\hline & & $\mathrm{TN}$ & $\mathrm{TN}=55.895-1.032 \mathrm{FarmL}$ & $\begin{array}{c}0.78 \\
5\end{array}$ & 0.713 & $\begin{array}{c}0.04 \\
5\end{array}$ \\
\hline & \multirow{3}{*}{$300 \mathrm{~m}$} & COD & Variable removed & - & - & - \\
\hline & & $\mathrm{TP}$ & $\mathrm{TP}=2.515-0.057$ FarmL & $\begin{array}{c}0.79 \\
4\end{array}$ & 0.725 & $\begin{array}{c}0.04 \\
2\end{array}$ \\
\hline & & $\mathrm{TN}$ & $\mathrm{TN}=79.528-1.863$ FarmL & $\begin{array}{c}0.95 \\
3\end{array}$ & 0.937 & $\begin{array}{c}0.00 \\
4\end{array}$ \\
\hline & \multirow{3}{*}{$500 \mathrm{~m}$} & COD & Variable removed & - & - & - \\
\hline & & $\mathrm{TP}$ & $\mathrm{TP}=2.46-0.06$ FarmL & $\begin{array}{c}0.81 \\
3\end{array}$ & 0.751 & $\begin{array}{c}0.03 \\
6\end{array}$ \\
\hline & & $\mathrm{TN}$ & $\mathrm{TN}=77.098-1.938 \mathrm{FarmL}$ & $\begin{array}{c}0.95 \\
8\end{array}$ & 0.944 & $\begin{array}{c}0.00 \\
4\end{array}$ \\
\hline & \multirow{3}{*}{$700 \mathrm{~m}$} & COD & Variable removed & - & - & - \\
\hline & & TP & $\mathrm{TP}=2.638-0.067 \mathrm{FarmL}$ & $\begin{array}{c}0.87 \\
0\end{array}$ & 0.827 & $\begin{array}{c}0.02 \\
1\end{array}$ \\
\hline & & $\mathrm{TN}$ & $\mathrm{TN}=81.143-2.11 \mathrm{FarmL}$ & $\begin{array}{c}0.98 \\
0\end{array}$ & 0.973 & $\begin{array}{c}0.00 \\
1\end{array}$ \\
\hline & \multirow{3}{*}{$1000 \mathrm{~m}$} & COD & Variable removed & - & - & - \\
\hline & & $\mathrm{TP}$ & $\mathrm{TP}=2.768-0.073 \mathrm{FarmL}$ & $\begin{array}{c}0.85 \\
4\end{array}$ & 0.805 & $\begin{array}{c}0.02 \\
5\end{array}$ \\
\hline & & $\mathrm{TN}$ & $\mathrm{TN}=85.869-2.319$ FarmL & $\begin{array}{c}0.97 \\
7\end{array}$ & 0.969 & $\begin{array}{c}0.00 \\
1\end{array}$ \\
\hline
\end{tabular}

